\title{
The Various Oximetric Techniques Used for the Evaluation of Blood Oxygenation
}

\author{
Meir Nitzan ${ }^{1, *}$, Itamar Nitzan ${ }^{2,3}$ and Yoel Arieli ${ }^{1}$ \\ 1 Department of Physics/Electro-Optics Engineering, Jerusalem College of Technology, 21 Havaad Haleumi St., \\ Jerusalem 91160, Israel; arieli@jct.ac.il \\ 2 Monash Newborn, Monash Children's Hospital, Melbourne 3168, Australia; itamarnitzan@gmail.com \\ 3 Department of Neonatology, Shaare Zedek Medical Center, Shmuel Bait St 12, Jerusalem 9103102, Israel \\ * Correspondence: Nitzan@g.jct.ac.il
}

Received: 5 August 2020; Accepted: 25 August 2020; Published: 27 August 2020

check for updates

\begin{abstract}
Adequate oxygen delivery to a tissue depends on sufficient oxygen content in arterial blood and blood flow to the tissue. Oximetry is a technique for the assessment of blood oxygenation by measurements of light transmission through the blood, which is based on the different absorption spectra of oxygenated and deoxygenated hemoglobin. Oxygen saturation in arterial blood provides information on the adequacy of respiration and is routinely measured in clinical settings, utilizing pulse oximetry. Oxygen saturation, in venous blood $\left(\mathrm{SvO}_{2}\right)$ and in the entire blood in a tissue $\left(\mathrm{StO}_{2}\right)$, is related to the blood supply to the tissue, and several oximetric techniques have been developed for their assessment. $\mathrm{SvO}_{2}$ can be measured non-invasively in the fingers, making use of modified pulse oximetry, and in the retina, using the modified Beer-Lambert Law. $\mathrm{StO}_{2}$ is measured in peripheral muscle and cerebral tissue by means of various modes of near infrared spectroscopy (NIRS), utilizing the relative transparency of infrared light in muscle and cerebral tissue. The primary problem of oximetry is the discrimination between absorption by hemoglobin and scattering by tissue elements in the attenuation measurement, and the various techniques developed for isolating the absorption effect are presented in the current review, with their limitations.
\end{abstract}

Keywords: blood oxygenation; oximetry; oxygenated and deoxygenated hemoglobin; light absorption spectra; modified Beer-Lambert Law; oxygen saturation; pulse oximetry; photoplethysmography; near infrared spectroscopy; accuracy

\section{Introduction}

Adequate oxygen delivery to tissue is essential for cellular metabolism, in which ATP energy-carrying molecules are produced from oxygen and nutrients. Since oxygen is transported from the lungs to the tissue cells via arterial blood, adequate oxygen supply to a tissue requires sufficient blood flow to the tissue and sufficient oxygen content in arterial blood, $\mathrm{CaO}_{2}$ (in $\mathrm{mL}$ oxygen per $\mathrm{L}$ blood). The latter is related to the hemoglobin concentration in blood, $[\mathrm{Hb}](\mathrm{g} / \mathrm{L})$, and arterial oxygen saturation, $\mathrm{SaO}_{2}$, (defined as the ratio of oxygenated hemoglobin concentration to total hemoglobin in arterial blood) according to the following relationship [1,2]:

$$
\mathrm{CaO}_{2}(\mathrm{~mL} / \mathrm{L})=1.36[\mathrm{Hb}] \mathrm{SaO}_{2}+0.0031 \mathrm{PaO}_{2}
$$

where $\mathrm{PaO}_{2}$ is arterial oxygen tension (mmHg). The factor 1.36 in Equation (1) stems from the maximal oxygen binding capacity of hemoglobin: $1.36 \mathrm{~mL}$ of oxygen in $1 \mathrm{~g}$ of hemoglobin. The value of $0.0031 \mathrm{PaO}_{2}$ is the dissolved oxygen content in the arterial blood plasma, and is very small relative to the oxygen content carried by the hemoglobin. 
Oxygen saturation, together with concentrations of oxygenated and deoxygenated hemoglobin $\left(\mathrm{HbO}_{2}\right.$ and $\mathrm{dHb}$, respectively), are quantitative parameters that allow the assessment of blood oxygenation. $\mathrm{SaO}_{2}$ provides information on the adequacy of respiration and ventilation. Oxygen saturation in venous blood, $\mathrm{SvO}_{2}$, also has clinical and physiological significance, because an increase in tissue metabolism requirements or a decrease in blood flow to the tissue lead to greater oxygen extraction by the tissue cells and consequently, to a decrease in oxygen saturation in the blood drained from the tissue by its veins. $\mathrm{SvO}_{2}$ is therefore directly related to the blood supply to the tissue that is drained by the vein and inversely related to its metabolism demand. The oxygen saturation in a tissue, $\mathrm{StO}_{2}$, is the ratio of oxygenated hemoglobin to total hemoglobin in the entire blood in the tissue-arterial and venous. $\mathrm{StO}_{2}$ is directly related to tissue blood flow and inversely related to its metabolism requirements. i.e., $\mathrm{StO}_{2}$ provides information on the adequacy of the blood supply to the tissue.

Oximetry is a technique for the assessment of blood oxygenation by optical measurements of light transmission through the blood, which is based on the different absorption spectra of $\mathrm{HbO}_{2}$ and $\mathrm{dHb}$. Figure 1 presents the molar extinction coefficients of $\mathrm{HbO}_{2}$ and $\mathrm{dHb}$ (the latter is denoted as $\mathrm{Hb}$ in the figure) as a function of the wavelength, in the visible and near infrared wavelength regions [3] (the molar extinction coefficient is defined as the absorption constant per molar and is actually a specific absorption constant). A great difference between the extinction coefficients of $\mathrm{HbO}_{2}$ and $\mathrm{dHb}$ appears for some wavelengths in the visible region, motivating their use for the oximetric assessment of blood oxygenation. However, light in the visible wavelength region below $650 \mathrm{~nm}$ is subjected to substantial absorption, and the transmitted light through tissue might have a low signal-to-noise ratio, even for a tissue with a small optical pathlength, such as the fingertip. Commonly, light in the red and infrared regions is utilized for measurements of light absorption in the fingertip and light in the near infrared region is preferred for measurements of light absorption in thicker tissue. Light in the visible region can also be used for oximetric measurements [4-7], mainly in the reflection mode.

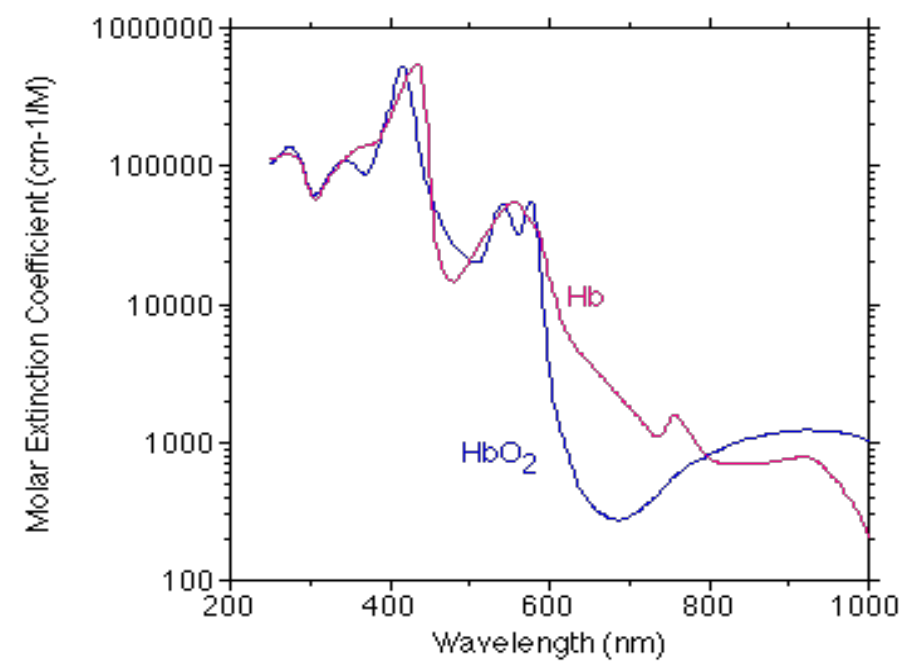

Figure 1. Molar extinction coefficients of oxygenated (blue curve) and deoxygenated hemoglobin (red curve) as a function of the wavelength in the visible and near infrared regions. Prepared by Scott Prahl from a variety of sources [3] and is presented with permission from Dr. Prahl.

The assessment of the oxygen saturation and $\mathrm{HbO}_{2}$ and $\mathrm{dHb}$ concentrations in the arterial and/or venous blood from measurements of light absorption (based on the different absorption spectra of $\mathrm{HbO}_{2}$ and $\mathrm{dHb}$ ) is interfered by the scattering of the light when propagating through the tissue. The optical parameter measured in oximetry is attenuation, the reduction in intensity of light passing through the tissue, and both absorption and scattering contribute to the attenuation. Light is scattered when it is refracted at the border between two media with different refractive indices, such as the surface between 
intra and extracellular fluids. Scattering contributes to attenuation by the loss of light deflected from its trajectory, and also indirectly, by an increase in the optical pathlength and consequently, an increase in the absorption by the $\mathrm{HbO}_{2}$ and $\mathrm{dHb}$ molecules. The differentiation between the absorption and scattering components of the attenuation measurement is the primary problem in oximetry and various methods have been developed in the various oximetric techniques for isolation of the absorption component. The scattering constant in tissue and in whole blood monotonically decreases with light wavelength, but the slope is moderate relative to that of the hemoglobin absorption constant. Several studies present curves of reduced scattering coefficient $\mu_{s}{ }^{\prime}$ in tissue [8,9] and in whole blood [10] as a function of light wavelength. $\mu_{\mathrm{s}}{ }^{\prime}$ is defined by $\mu_{\mathrm{s}}{ }^{\prime}=\mu_{\mathrm{s}}(1-\mathrm{g})$ where $\mu_{\mathrm{s}}$ is the scattering constant and $\mathrm{g}$ is the anisotropy [11,12]. The path that the photon propagates before being scattered is represented by $1 / \mu_{s}$; the path the photon propagates before entirely losing its direction is represented by $1 / \mu_{s}{ }^{\prime}$.

The current review presents the main oximetric techniques that have been developed for the evaluation of oxygenation parameters in arterial, venous and tissue blood. The oxygenation parameters are derived from optical attenuation measurements, and the review mainly concentrates on the different approaches for isolating the absorption component from the entire attenuation effect. The degree of differentiation between the absorption and scattering effects is a pivotal determinant for the accurate assessment of oxygen saturation in any oximetric method.

\section{Oximetry-General Theory}

Oximetry is a technique for the evaluation of blood oxygenation level in arteries, veins, or in entire blood in tissue, by optical transmission measurements, utilizing the different absorption spectra of $\mathrm{HbO}_{2}$ and $\mathrm{dHb}$. The blood oxygenation parameters are oxygen saturation and $\mathrm{HbO}_{2}$ and $\mathrm{dHb}$ concentrations in the arterial and/or venous blood. In order to measure the absorption, light with wavelength spectra in the red and/or infrared regions is irradiated into a tissue and its transmission through the tissue is measured. During its passage through the tissue, the light undergoes absorption, mainly by the hemoglobin molecules in the red blood cells, and scattering by tissue elements and the red blood cells. The light absorption that depends on the oxygenation level is the signal and the light scattering that is insensitive to the oxygenation level [10] is a noise, and suitable isolation of the contribution of the absorption to the light attenuation is essential for the accurate evaluation of blood oxygenation level. In order to derive the blood oxygenation from the light absorption measurement, the values of $\varepsilon_{\mathrm{O}}$ and $\varepsilon_{\mathrm{D}}$, the extinction coefficients of $\mathrm{HbO}_{2}$ and $\mathrm{dHb}$, respectively (Figure 1), are required, and they were obtained by measuring the absorption constant in scattering-free hemoglobin molecule solution, after fragmentation of the red blood cells (hemolysis) [13]. The transmitted light intensity, $\mathrm{I}_{\mathrm{t}}$, through a sample of homogeneous solution of hemoglobin molecules, is given by the Beer-Lambert law,

$$
\mathrm{I}_{\mathrm{t}}=\mathrm{I}_{0} \exp (-\varepsilon \mathrm{Cd})
$$

where $\mathrm{I}_{0}$ is the intensity of the incident light, $\mathrm{d}$ is the width of the hemoglobin solution (the source-detector distance), $\varepsilon$ is the hemoglobin solution extinction coefficient and $C$ is the hemoglobin concentration.

The transmitted light intensity, $\mathrm{I}_{\mathrm{t}}$, through a scattering tissue sample, is given by the modified Beer-Lambert law [12,14]:

$$
\mathrm{I}_{\mathrm{t}}=\mathrm{I}_{0} \exp (-\mathrm{G}-\varepsilon \mathrm{Cl}) ; \ln \left(\mathrm{I}_{0} / \mathrm{I}_{\mathrm{t}}\right)=\mathrm{G}+\varepsilon \mathrm{Cl}
$$

where $\mathrm{I}_{0}$ is the intensity of the incident light and $l$ is the mean optical path-length. $l$ is greater than $\mathrm{d}$ because of scattering by the red blood cells and the tissue elements. The ratio $l / d$ is named the differential pathlength factor (DPF) and it depends on the light scattering and absorption [12,14]. G represents the light-loss due to tissue scattering and depends on the light-sources and detector geometry. In the transmission mode of measurement, $\mathrm{G}$ represents the light-loss due to light deflection from a straight-line trajectory, while in the reflection mode (where the light-source and 
the detector are positioned on the same side of the tissue sample), $\mathrm{G}$ is more complex, as scattering also enables the diversion of light towards the detector.

The weighted mean extinction coefficient $\varepsilon$ of the blood in the vessels of the tissue sample depends on the oxygen saturation $\mathrm{SO}_{2}$ in the tissue blood:

$$
\varepsilon=\varepsilon_{\mathrm{O}} \mathrm{SO}_{2}+\varepsilon_{\mathrm{D}}\left(1-\mathrm{SO}_{2}\right) .
$$

Combining Equations (3) and (4), a linear relationship between the physiological parameter $\mathrm{SO}_{2}$ and the measured parameter $\ln \left(\mathrm{I}_{0} / \mathrm{I}_{\mathrm{t}}\right)$ can be obtained:

$$
\ln \left(\mathrm{I}_{0} / \mathrm{I}_{\mathrm{t}}\right)=\mathrm{G}+\varepsilon \mathrm{Cl}=\mathrm{G}+\varepsilon_{\mathrm{D}} \mathrm{Cl}+\mathrm{Cl}\left(\varepsilon_{\mathrm{O}}-\varepsilon_{\mathrm{D}}\right) \mathrm{SO}_{2} .
$$

C, (in units of molar), is either the hemoglobin concentration in tissue, when the measurement is done on blood in tissue, or the hemoglobin concentration in a blood sample in a blood vessel. If light is transmitted through a tissue, other substances, such as melanin, myoglobin and cytochrome, might also affect the absorption.

In order to derive $\mathrm{SO}_{2}$ from measurement of $\ln \left(\mathrm{I}_{0} / \mathrm{I}_{\mathrm{t}}\right)$ through Equation (5), the three unknowns, G, $C$ and $l$, should be considered. The two effects of scattering, the light deflection and the lengthening of the optical path-length, considerably affect the light attenuation and prevent quantitative derivation of oxygen saturation from light transmission measurements. In addition, G and DPF change considerably among different persons, tissues and situations, and quantitative measurement of them in each examination is impractical. In oximetry, transmission measurement, in two or three wavelengths, has been utilized to reduce the harmful effect of the scattering in oximetry. The benefit of two-wavelength oximetry arises from the considerable spectral dependence of the difference in extinction coefficient between $\mathrm{HbO}_{2}$ and $\mathrm{Hb}$, while the spectral changes in scattering are moderate [8-10].

\section{Non-Pulsatile Oximetric Techniques}

\subsection{In-Vitro Measurements}

Early in vitro oximetric measurements of oxygen saturation in whole blood (blood that contained intact red blood cells) were based on the assumption that light absorption and scattering can be treated independently - the theory of Twersky [15-17]. Then, the modified Beer-Lambert law can be written as $\mathrm{OD}=\mathrm{G}+\varepsilon \mathrm{cd}$, where $\mathrm{OD}$ is the optical density $\left(\mathrm{OD}=\log _{10}\left(\mathrm{I}_{0} / \mathrm{I}_{\mathrm{t}}\right)=\ln \left(\mathrm{I}_{0} / \mathrm{I}_{\mathrm{t}}\right) / 2.3\right)$. In this equation, the source-detector distance, $d$, was used as the pathlength (instead of $l$ in Equation (3)), neglecting the effect of scattering by red blood cells on pathlength elongation.

Pittman [16] isolated the contribution of scattering to attenuation by measuring the optical density at two wavelengths (546 and $520 \mathrm{~nm}$ ), for which the extinction coefficients of $\mathrm{dHb}$ and $\mathrm{HbO}_{2}$ were equal (isosbestic wavelengths) and their scattering effect was similar, because they were close to each other. $\mathrm{SO}_{2}$ could be obtained from an additional measurement of the optical density at a third wavelength $(555 \mathrm{~nm})$ in which the extinction coefficients of $\mathrm{Hb}$ and $\mathrm{HbO}_{2}$ showed a large difference. $\mathrm{SO}_{2}$ was determined from the corrected optical densities at the wavelengths $555 \mathrm{~nm}$ and one of the isosbestic wavelengths: $(\mathrm{OD}(555)-\mathrm{G}) /(\mathrm{OD}(520)-\mathrm{G})$. The three-wavelength technique with two isosbestic wavelengths was also used later in retinal oximetry [18-20], dealt with in Section 4.3.

Iwasaki et al. [17] measured the oxygen saturation of whole blood collected from rabbits by means of a fiber-optic catheter inserted in the blood (see Figure 2). They used two wavelengths, an isosbestic one of $805 \mathrm{~nm}$, and another of $670 \mathrm{~nm}$, for which the extinction coefficients of $\mathrm{dHb}$ and $\mathrm{HbO}_{2}$ showed a great difference. Based on the theory of Twersky, they employed an expression:

$$
\mathrm{SO}_{2}=\left(\mathrm{k}_{1} / \mathrm{C}_{\mathrm{Hb}}\right)\left(\mathrm{OD}_{670}-\mathrm{OD}_{805}\right)+\mathrm{k}_{2}
$$


where $\mathrm{C}_{\mathrm{Hb}}$ is the total hemoglobin concentration and $\mathrm{k}_{1}$ and $\mathrm{k}_{2}$ are constants that depend on the catheter geometry and hemoglobin extinction coefficients. $\mathrm{OD}_{670}$ and $\mathrm{OD}_{805}$ are the measured optical densities at $670 \mathrm{~nm}$ and $805 \mathrm{~nm}$, respectively.

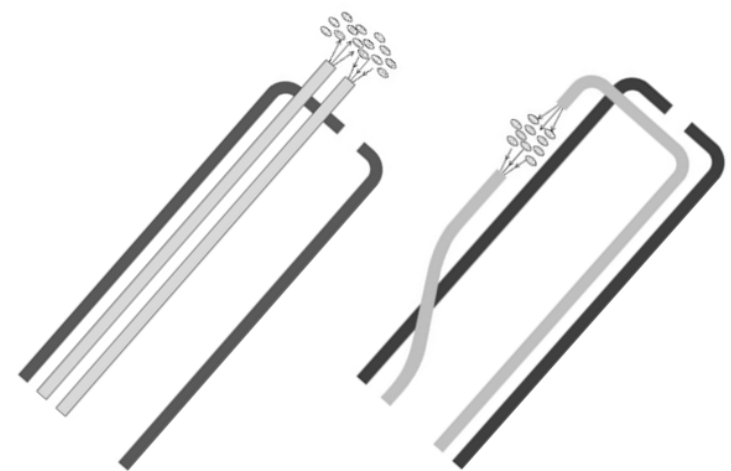

Figure 2. Reflection (left) and transmission (right) fiber-optic intravenous blood oximeters. The emission and measuring optic fibers are drawn in grey, the catheter wall is drawn in black.

Equation (6) was validated in-vitro on a blood sample, making use of $\mathrm{SO}_{2}$ measured by a commercial oximeter (Radiometer), which employed two wavelengths in the visible range, $505 \mathrm{~nm}$ and $600 \mathrm{~nm}$. The correlation between the two oximetric techniques was $0.99(p<0.001)$ for a saturation range of $13-100 \%$, with standard deviation of $1.1 \%$.

\subsection{Tissue Oximetry}

An oximeter that utilized red and green light transmission through the outer ear was developed during World War II [21]. Red light is more sensitive to the hemoglobin oxygenation level than broadband green light (Figure 1). The study included a series of examinations, each comprised an initial calibration by comparing in vivo measurement during pure oxygen breathing, and measurement on extracted arterial blood with $100 \%$ saturation. Then, in vivo measurements were performed, in which the oxygen level in the inspired air was lowered. The calibration enabled the elimination of the scattering effects and the effect of light absorption by venous blood. The accuracy of the device, as determined by gas analysis of arterial blood samples, was 3-8\%.

An ear oximeter that did not require calibration in each examination, but only pre-calibration, was developed by Hewlett-Packard in the 1970's, (at about the same time as that of pulse oximetry invention), using eight wavelengths, from $650 \mathrm{~nm}$ to $1050 \mathrm{~nm}$. The ear was chosen because its high blood flow is in excess of its metabolic needs, as it serves as a heat radiator. The coefficients required for the determination of arterial oxygen saturation from the optical measurements were derived by pre-calibration, using simultaneous measurements of light transmission and oxygen saturation in arterial blood extracted from volunteers that were performed in different oxygen saturation values, obtained by breathing different gas mixtures [22-24].

The calibration process could take account of the contribution of non-hemoglobin tissue absorbers and the scattering by the tissue and red blood cells. In order to compensate for changes in venous blood concentration, ear temperature was increased to $41^{\circ} \mathrm{C}$ (or vasodilator cream was applied to the ear), "arterializing" the venous and capillary blood. The Hewlett-Packard eight-wavelength oximeter was compared to another oximeter (Radiometer), and showed a standard error of estimate of $2-2.5 \%$ [22-24].

The Hewlett-Packard oximeter has not been produced since 1983 [25], because the pulse oximeter that was invented in 1972 by Takuo Aoyagi [26] has been found to be more suitable for clinical practice. In a subsequent section, it will be described how pulse oximetry, after pre-calibration, solved the problems of interference of scattering and absorption in venous blood in a more practical way. 


\subsection{Intravenous Blood Oximetry}

As described in the Introduction section, the oxygen saturation in a vein's blood, $\mathrm{SvO}_{2}$, is related to the blood supply to the tissue that is drained by the vein. Of particular significance is the oxygen saturation in the pulmonary artery that carries the mixed venous blood-the entire venous blood returning from the body organs supplied by the systemic circulation-and in the jugular veins, which drain the blood from the brain. $\mathrm{SvO}_{2}$ in the pulmonary artery and in the jugular vein are directly related to the cardiac output and brain blood supply, respectively, and inversely related to the oxygen demand in the respective tissue.

Mixed venous oxygen saturation in the pulmonary artery can be obtained by introducing a Swan-Ganz catheter into the pulmonary artery and measuring the oxygen saturation in an extracted sample of mixed venous blood via blood gases analysis. Pulmonary artery catheters are introduced through a central vein, the right atrium and ventricle, and because their use has been limited, measurement of oxygen saturation in central veins-superior and inferior vena cava-has been suggested as a surrogate for mixed venous oxygen saturation measurement [27-29].

Monitoring oxygen saturation by intermittent measurement in extracted blood samples has several drawbacks, and intravenous blood oximetry has been developed for continuous monitoring of oxygen saturation in veins' blood. The oximetric probe consisted of two optical fibers with a small gap between their tips (Figure 2), which was introduced into the vein. One of the fibers transmits two-wavelengths of light into the blood in the gap between the optical fibers and the second fiber guides the transmitted light to the detector $[17,29,30]$.

The $\mathrm{SvO}_{2}$ value was calculated from the values of the transmitted light in two or three wavelengths by using the modified Beer-Lambert law [17,30]. Like the Millikan's oximeter, the intravenous oximeter needs calibration in a blood sample before each continuous examination, according to the manufacturer's instructions, using blood gases analysis. Limits of agreement of 7-16\% were found between the optical measurement and blood gases analysis on blood samples extracted from the same vein [28,29].

Besides its use in the central veins, the intravenous blood oximeter has also been implemented for the measurement of oxygen saturation in the jugular vein, which drains blood from the brain. However, while low $\mathrm{SvO}_{2}$ in the jugular vein's blood faithfully indicates inadequate oxygen supply to the brain, normal values of jugular oxygen saturation cannot ascertain adequate oxygen delivery to each brain site, because insufficient oxygen supply to a small region of the brain might only slightly affect $\mathrm{SvO}_{2}$ in the jugular vein, which drains blood from the entire brain hemisphere [31,32]. Several studies showed an association between abnormalities in jugular $\mathrm{SvO}_{2}$ and poor outcomes in patients after traumatic brain injury [33-35].

\section{Pulse Oximetry-Theory and Techniques}

\subsection{Theory of Arterial Pulse Oximetry}

The pulse oximeter, which measures the oxygen saturation in the arterial blood, $\mathrm{SaO}_{2}$, was invented in 1972 by Takuo Aoyagi, an electrical engineer at the Nihon Kohden company in Tokyo [26]. Pulse oximetry evaluates the $\mathrm{SaO}_{2}$ level by optical transmission measurements in two wavelengths, utilizing the different absorption spectra of $\mathrm{HbO}_{2}$ and $\mathrm{dHb}$, like the other oximetric techniques. In order to measure oxygen saturation only in the arterial blood, the light absorption is measured selectively in the systolic increments of arterial blood volume after ventricular contraction, by recording heart-induced oscillations in light absorption-photoplethysmography (PPG).

The theory of pulse oximetry has been described in several publications [36-40]. In the current review, the theory and its assumptions will be presented in detail, in order to demonstrate its limitations and its relationship to the other oximetric techniques.

A finger PPG signal is shown in Figure 3, presenting the decrease in transmitted light intensity through the finger during systole and the light intensity increase during diastole, due to the systolic increase and diastolic decrease in the arterial blood volume. The maximal and minimal values of 
the PPG pulse ( $\mathrm{I}_{\mathrm{D}}$ and $\mathrm{I}_{\mathrm{S}}$ in Figure 3, respectively) are proportional to the light transmission through the tissue at end-diastole and at end-systole, when tissue blood volume is minimal and maximal, respectively. The analysis of the PPG pulses enables the isolation of the arterial blood contribution to the entire light absorption.

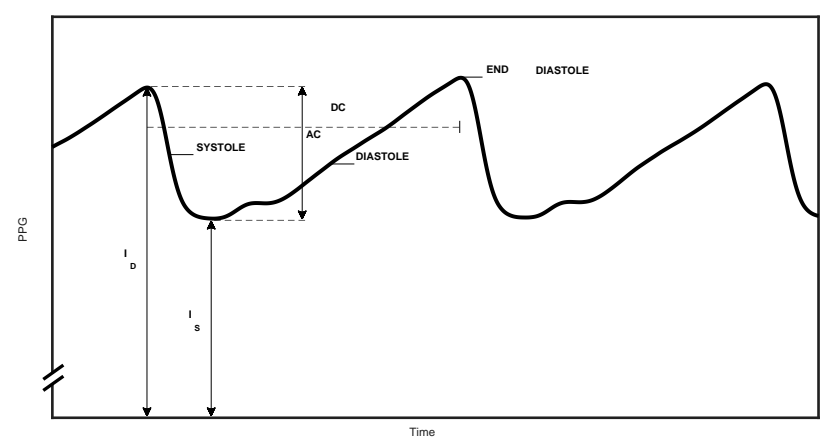

Figure 3. The measured parameters of the PPG pulses. The transmitted light through the tissue decreases during systole and increases during diastole. $\mathrm{AC}$ is the difference between the maximal $\left(\mathrm{I}_{\mathrm{D}}\right)$ and minimal $\left(\mathrm{I}_{\mathrm{S}}\right)$ light transmission through the tissue; DC is the mean light transmission during the pulse. This Figure was published in Yossef Hay et al. Sensors 2018 [41].

Substitution of the $I_{D}$ and $I_{S}$ values for $I_{t}$ in Equation (3), and division of the resultant two equations, eliminate the value of $\mathrm{I}_{0}$, and provide an equation for $\mathrm{I}_{\mathrm{D}} / \mathrm{I}_{\mathrm{S}}$ :

$$
\mathrm{I}_{\mathrm{S}}=\mathrm{I}_{\mathrm{D}} \exp \left(\mathrm{G}_{\mathrm{D}}+\varepsilon \mathrm{C}_{\mathrm{D}} l_{\mathrm{D}}\right) \exp \left(-\mathrm{G}_{\mathrm{S}}-\varepsilon \mathrm{C}_{\mathrm{S}} l_{\mathrm{S}}\right) ; \ln \left(\mathrm{I}_{\mathrm{D}} / \mathrm{I}_{\mathrm{S}}\right)=\mathrm{G}_{\mathrm{D}}-\mathrm{G}_{\mathrm{S}}+\varepsilon \mathrm{C}_{\mathrm{D}} l_{\mathrm{D}}-\varepsilon \mathrm{C}_{\mathrm{S}} l_{\mathrm{S}}
$$

The $D$ or $S$ subscripts indicate the parameter values at diastole or systole, respectively. $G_{D}, G_{S}$, $l_{\mathrm{D}}$ and $l_{\mathrm{S}}$ are unknown, but it can be assumed that the changes in $\mathrm{G}$ and $l$ due to the systolic arterial blood increment can be neglected relative to the absorption effect $\left(\mathrm{G}_{\mathrm{D}} \approx \mathrm{G}_{\mathrm{S}}, l_{\mathrm{D}} \approx l_{\mathrm{S}} \approx l\right)$. Accordingly, Equation (7) can be written as:

$$
\ln \left(\mathrm{I}_{\mathrm{D}} / \mathrm{I}_{\mathrm{S}}\right)=\varepsilon \Delta \mathrm{Cl}
$$

The PPG amplitude, $\mathrm{I}_{\mathrm{D}}-\mathrm{I}_{\mathrm{S}}$, is generally small relative to $\mathrm{I}_{\mathrm{S}}$, and Equation (8) can be written as:

$$
\left(\mathrm{I}_{\mathrm{D}}-\mathrm{I}_{\mathrm{S}}\right) / \mathrm{I}_{\mathrm{S}}=\varepsilon \Delta \mathrm{Cl}
$$

where $\Delta \mathrm{C}$ is the maximal hemoglobin concentration increase in the tissue during systole, due to the arterial blood volume increase. $\varepsilon$ is the extinction coefficient for the arterial blood, which includes both oxi- and deoxi-hemoglobin, and depends on the oxygen saturation in the arterial blood, $\mathrm{SaO}_{2}$.

When light transmission is measured in two wavelengths, $\lambda_{1}$ and $\lambda_{2}$, Equation (9) becomes:

$$
\left[\left(\mathrm{I}_{\mathrm{D}}-\mathrm{I}_{\mathrm{S}}\right) / \mathrm{I}_{\mathrm{S}}\right]_{1}=\varepsilon_{1} \Delta \mathrm{C}_{1} l_{1} ;\left[\left(\mathrm{I}_{\mathrm{D}}-\mathrm{I}_{\mathrm{S}}\right) / \mathrm{I}_{\mathrm{S}}\right]_{2}=\varepsilon_{2} \Delta \mathrm{C}_{2} l_{2}
$$

In pulse oximeters, the light in two wavelengths is emitted from two adjacent light-emitting diodes (LEDs) and the transmitted light is measured by a single detector. Since the light of the two wavelengths propagates through the same tissue element, the blood concentration change, $\Delta C$, in the measurement site for the two wavelengths can be considered equal $\left(\Delta \mathrm{C}_{1} \approx \Delta \mathrm{C}_{2}\right)$.

By dividing the equations in Equation (10) one gets:

$$
\mathrm{R} \equiv \frac{\left[\left(\mathrm{I}_{\mathrm{D}}-\mathrm{I}_{\mathrm{S}}\right) / \mathrm{I}_{\mathrm{S}}\right)_{1}}{\left[\left(\mathrm{I}_{\mathrm{D}}-\mathrm{I}_{\mathrm{S}}\right) / \mathrm{I}_{\mathrm{S}}\right)_{2}}=\frac{\varepsilon_{1} l_{1}}{\varepsilon_{2} l_{2}}
$$

If we further assume that $l_{1}$ is not much different than $l_{2}$, then

$$
\mathrm{R} \approx \varepsilon_{1} / \varepsilon_{2}
$$


Substitution of Equation (4) in Equation (12) provides a relationship between the measured parameter $\mathrm{R}$ and the physiological parameter $\mathrm{SaO}_{2}$ :

$$
\mathrm{R}=\frac{\varepsilon_{\mathrm{D} 1}+\mathrm{SaO}_{2}\left(\varepsilon_{\mathrm{O} 1}-\varepsilon_{\mathrm{D} 1}\right)}{\varepsilon_{\mathrm{D} 1}+\mathrm{SaO}_{2}\left(\varepsilon_{\mathrm{O} 2}-\varepsilon_{\mathrm{D} 2}\right)}
$$

and

$$
\mathrm{SaO}_{2}=\frac{\varepsilon_{\mathrm{D} 1}-\mathrm{R} \varepsilon_{\mathrm{D} 2}}{\mathrm{R}\left(\varepsilon_{\mathrm{O} 2}-\varepsilon_{\mathrm{D} 2}\right)+\left(\varepsilon_{\mathrm{D} 1}-\varepsilon_{\mathrm{O} 1}\right)}
$$

Equation (14) could provide the required relationship between $\mathrm{SaO}_{2}$ and $\mathrm{R}$, since the values of $\varepsilon_{\mathrm{O}}$ and $\varepsilon_{\mathrm{D}}$, the extinction coefficients for $\mathrm{HbO}_{2}$ and $\mathrm{dHb}$, are known for wavelengths in the red and infrared regions [42,43]. However, the assumption that $l_{1}$ is not much different than $l_{2}$ (Equation (12)) can introduce significant error in the calculation of $\mathrm{SaO}_{2}$, when the two wavelengths differ significantly, since the optical path-length increases by light scattering and the scattering constant decreases monotonically with the wavelength [8-10]. In the commercial pulse oximeters that make use of two wavelengths in the red and infrared regions, a non-negligible difference in optical path-lengths between the two wavelengths is expected.

If the difference between $l_{2}$ and $l_{1}$ is not neglected, Equation (12) should be modified to

$$
\mathrm{R}\left(l_{2} / l_{1}\right)=\varepsilon_{1} / \varepsilon_{2}
$$

Furthermore, by replacing $\mathrm{R}$ in Equation (14) with $\mathrm{R}\left(l_{2} / l_{1}\right)$, the relationship between $\mathrm{SaO}_{2}$ and $\mathrm{R}$ becomes $[39,41,44]$ :

$$
\mathrm{SaO}_{2}=\frac{\varepsilon_{\mathrm{D} 1}-\mathrm{R}\left(l_{2} / l_{1}\right) \varepsilon_{\mathrm{D} 2}}{\mathrm{R}\left(l_{2} / l_{1}\right)\left(\varepsilon_{\mathrm{O} 2}-\varepsilon_{\mathrm{D} 2}\right)+\left(\varepsilon_{\mathrm{D} 1}-\varepsilon_{\mathrm{O} 1}\right)}
$$

Generally, the factor $l_{2} l_{1}$ is not known with reasonable accuracy and $\mathrm{SaO}_{2}$ cannot be derived from the measured value of $\mathrm{R}$ by Equation (16). In practice, $\mathrm{SaO}_{2}$ is obtained from the measured parameter $\mathrm{R}$ by calibration, for each kind of pulse oximeter sensor [37,38,45,46]: $\mathrm{R}$ is measured for a number of subjects simultaneously with in vitro $\mathrm{SaO}_{2}$ measurement in extracted arterial blood by means of a co-oximeter (the gold-standard for $\mathrm{SO}_{2}$ measurements). For each person, $\mathrm{R}$ and the corresponding $\mathrm{SaO}_{2}$ are measured for several values of oxygen partial pressure in the inspired air, and a look-up table is prepared from the $\mathrm{R}-\mathrm{SaO}_{2}$ pairs. In clinical examinations, $\mathrm{SaO}_{2}$ is determined from the $\mathrm{R}$ value through an empirical function that was derived from the look-up table. The calibration enables the determination of $\mathrm{SaO}_{2}$ from the $\mathrm{R}$ measurement only, while the use of Equation (16) must utilize the value of $l_{2} / l_{1}$, which is not known with adequate precision.

Note that in general, in publications about pulse oximetry, the ratio of ratios, $\mathrm{R}$, is defined by means of the pulsatile and non-pulsatile (average) components of the detected PPG pulse: $\mathrm{R} \equiv(\mathrm{AC} / \mathrm{DC})_{1} /(\mathrm{AC} / \mathrm{DC})_{2}$, which seems to be different from the definition of $\mathrm{R}$ in Equation (11) (See Figure 3 for the definitions of $A C$ and DC). However, $A C$ is equal to $I_{D}-I_{S}$ and $D C$ is the average value of the PPG pulse during the cardiac cycle. DC is only slightly greater than $\mathrm{I}_{\mathrm{S}}$, assuming that $\mathrm{I}_{\mathrm{D}}-\mathrm{I}_{\mathrm{S}}$ is small relative to $\mathrm{I}_{\mathrm{S}}$.

The validity of the clinical measurements by the calibrated pulse oximeter is based on the assumption that the extinction coefficients and $l_{2} / l_{1}$ do not change significantly between different persons and different physiological and clinical situations. While the $\mathrm{HbO}_{2}$ and $\mathrm{dHb}$ extinction coefficients for a given wavelength are invariable, the scattering by tissue and red blood cells strongly depends on the substance and structure of the tissue and on the volume and anatomical arrangement of blood vessels in the tissue, which significantly varies among patients. It is expected that $l_{2} / l_{1}$ in a specific clinical examination might deviate from the mean $l_{2} / l_{1}$ value for the persons examined in the calibration process, and that deviation is probably the main origin of the inaccuracy in the assessment of $\mathrm{SaO}_{2}$ by pulse oximetry (See below). For wavelengths in the red and infrared regions, the differences 
between their scattering constants and pathlengths are great [8-10] and accordingly, the absolute variation in the pathlengths ratio, $l_{2} / l_{1}$, among patients is expected to be considerable.

The actual mean error in $\mathrm{SaO}_{2}$ measurement by the available commercial pulse oximeters is $3-4 \%$ for adults and $4-6 \%$ for newborns [47-54]. In the low $\mathrm{SaO}_{2}$ levels, below 80 or $90 \%$, the error is even greater $[50,51,53]$. Because of its low accuracy, arterial oxygen saturation measurement by pulse oximetry is denoted by $\mathrm{SpO}_{2}$, while the term $\mathrm{SaO}_{2}$ is generally reserved for arterial oxygen saturation measured by blood gases analysis in extracted blood. The accuracy in $\mathrm{SaO}_{2}$ measurement is of particular importance in preterm newborns treated with oxygen supplementation, because low oxygenation increases mortality while excessive oxygenation increases the risk of retinopathy of prematurity $[53,55,56]$. Accurate $\mathrm{SaO}_{2}$ measurement is also important in adult patients in intensive care units, treated with high concentrations of inspired oxygen, where hyperoxia is associated with greater mortality and morbidity $[57,58]$.

In the last few years, pulse oximetry that makes use of two close wavelengths in the infrared has been developed $[39,41,59]$. The choice of light with two close wavelengths reduces the differences between their scattering constants and path-lengths, so that the error due to the inter-subject variation in $l_{2} / l_{1}$ is expected to be small relative to that experienced for red and infrared pulse oximetry. In those studies, $\mathrm{SpO}_{2}$ was derived from Equation (14), using the values of the extinction-coefficients of $\mathrm{HbO}_{2}$ and $\mathrm{dHb}$, as presented in the articles of Kim and Liu [42,43], and neglecting the difference between $l_{2}$ and $l_{1}$. In the earlier study [39], simultaneous examinations of $\mathrm{SaO}_{2}$ were performed with two close wavelengths in the infrared region $(767$ and $811 \mathrm{~nm})$ and two wavelengths in the red and infrared regions (635 and $937 \mathrm{~nm}$ ), making use of Equation (14). The discrepancy of the results from a commercial pulse oximeter (that was calibrated by extracted blood) was $3 \%$ for the two-infrared wavelengths pair and $9 \%$ for the red-infrared pair, probably due to the greater deviation of the ratio $l_{2} / l_{1}$ from the value of 1 in the red-infrared pair. The bottom line is that the two-infrared pulse oximeter also needs calibration, but since the difference between $l_{2}$ and $l_{1}$ is small, the variability in $l_{2} l_{1}$ for the two-infrared pair of wavelengths is expected to be smaller than that for two wavelengths in the red and infrared regions.

In a recent study [41] on newborns and children with an arterial line, simultaneous measurements of $\mathrm{SpO}_{2}$, using two infrared wavelengths and $\mathrm{SaO}_{2}$ by blood gases analysis on extracted blood, were performed. The mean difference between $\mathrm{SaO}_{2}$ and $\mathrm{SpO}_{2}$ was 3\%, which was corrected by multiplying the $\mathrm{SpO}_{2}$ results by a calibration factor of 1.03. Compared to arterial line measurements, the standard-deviation of the two-infrared-wavelength $\mathrm{SpO}_{2}$ measurements was 3.3\%, similar to that of a commercial pulse oximeter (3.8\%).

\subsection{Pulse Oximetry of Venous Blood}

Oxygen saturation in venous blood has been measured by modified pulse oximetry, in which a pulsatile increase in venous blood volume was achieved either by applying pressure proximal to the measurement site—e.g., a finger [39,60]—or by mechanical ventilation [61,62]. The latter technique is based on the phenomenon that mechanical ventilation induces systemic blood volume changes and on the assumption that those changes are of venous origin. $\mathrm{SvO}_{2}$ was measured by Walton et al. on cardiac surgery patients making use of an esophageal PPG probe, and by Wolf et al. on cerebral tissue of infants. The two studies yielded saturation values around $80 \%$ [62] or 70\% [61], which are within the physiologic range of $\mathrm{SvO}_{2}$ in the relevant tissues.

In the two other studies [39,60], external pressure of $40-50 \mathrm{mmHg}$ was applied proximal to the measurement site, leading to an increase in venous blood volume, and two-wavelength light absorption was used for the measurement of $\mathrm{SvO}_{2}$. Nitzan et al. [39] used a single step increase in the cuff pressure and two close wavelengths in the infrared region in order to reduce the difference in their pathlengths (see end of Section 4.1). In the study of Khan et al. [60], artificial venous blood volume oscillations at a frequency of $0.2 \mathrm{~Hz}$ were induced by a pressure cuff, placed on the finger, proximal 
to a commercial pulse oximeter sensor. The interquartile range of the $\mathrm{SvO}_{2}$ difference between the venous pulse oximeter and a reference blood gas analyzer was $-2.05-1.27 \%$.

\subsection{Difference Oximetry in Single Arteries and Veins}

In pulse oximetry, the measurement of the attenuation difference between end-systole and end-diastole, given by $\ln \left(\mathrm{I}_{\mathrm{D}} / \mathrm{I}_{\mathrm{S}}\right)$, enables the determination of $\mathrm{SaO}_{2}$, by assuming that the difference in light-loss due to scattering between end-diastole and end-systole can be neglected relative to the absorption effect. In a similar way, difference oximetry was suggested for oxygen saturation measurements in a single blood vein, by introducing light in two wavelengths into the vein and measuring light reflection from two nearby sites in the vessel [63]. The method was found feasible by Monte Carlo simulation of light backscattering from a vein model.

In practice, difference oximetry has been implemented in oxygen saturation measurements in single retinal arteries and veins in the retina, by illuminating the eye fundus and acquiring its image through the eye's pupil, mostly with a fundus camera, exploiting the eye's transparency. Figure 4 presents light rays' trajectories from the eye's lens to the retina and scattered/reflected light from a retinal blood vessel and its neighborhood (See Hammer et al. [64]). Most of the light that reaches the retina is lost by scattering or absorption in blood vessels, but a small part of the scattered/reflected light is recorded by the camera. Retinal image analysis enables discrimination between scattered/reflected light from a blood vessel $\left(\mathrm{I}_{\mathrm{V}}\right)$ or from its neighborhood $\left(\mathrm{I}_{0 \mathrm{n}}\right)$. (Note that in retinal oximetry studies, scattered light from the vessel's neighborhood is denoted by $\mathrm{I}_{0}$. We changed the symbol; as in the Beer-Lambert law, $\mathrm{I}_{0}$ denotes the incident light, see Equations (2), (3) and (5)) Retinal oximetry is based on the assumptions that $\mathrm{I}_{0 \mathrm{n}}$ is unaffected by light absorption in the blood and the light-loss $\mathrm{G}$ due to scattering is similar for the two measurement sites, in analogy to pulse oximetry that assumes similarity in light-loss $\mathrm{G}$ for end-systole and end-diastole (see discussion after Equation (7)). Hence, the difference between $I_{v}$ and $I_{0 n}$ is assumed to stem from the light absorption in the vessel's blood, and the ratio between the optical densities for the two wavelengths enables the determination of oxygen saturation in the retinal vessel. It seems, however, that the assumption that $\mathrm{I}_{0 \mathrm{n}}$ is unaffected by light absorption in the blood is not fully justified, as can be inferred from Figure 4.

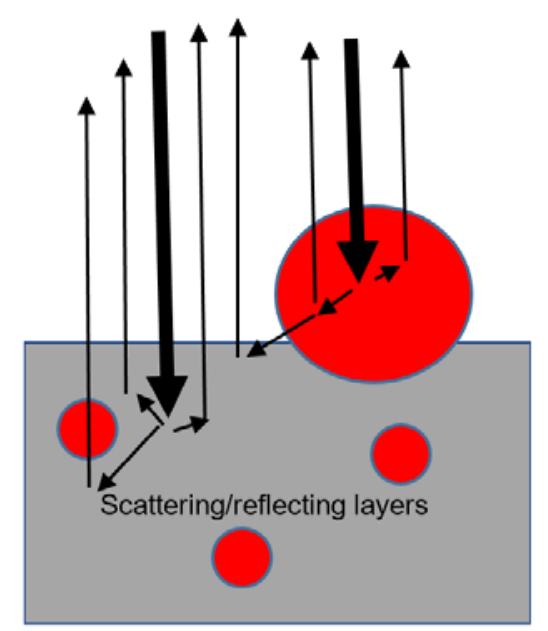

Figure 4. Schematic cross-section of the retina (grey), which includes cross-sections of a retinal vessel (arteriole or venule) and retinal capillaries (red), and possible trajectories of light that illuminates the retina. The incident light (broad black rays) illuminates the vessel and its neighborhood. The light that strikes the vessel and the neighboring tissue is scattered and backscattered by the blood and the tissue (thin rays). Most of the scattered/reflected light from the neighboring tissue is not affected by absorption in the blood, but some photons are affected by blood in the retinal vessel or the retinal capillaries. 
The optical density of the vessel $\left(\mathrm{OD}_{\mathrm{Ves}}\right)$ is defined as,

$$
\mathrm{OD}_{\mathrm{Ves}}=\log \left(\mathrm{I}_{0 \mathrm{n}} / \mathrm{I}_{\mathrm{V}}\right)
$$

reflecting the effect of light absorption in the vessel's blood. In practice, $\mathrm{OD}_{\mathrm{Ves}}$ is obtained along the image of the vessel and next to it. The retinal image is split into two images created with two wavelengths in the visible region: $\lambda_{1}$, in which the extinction coefficient substantially differs between $\mathrm{HbO}_{2}$ and $\mathrm{dHb}$, and $\lambda_{2}$ that is insensitive to oxygen saturation-an isosbestic wavelength. The image separation is performed either by an image splitter and appropriate filters [65,66], a double bandpass filter and the red and green camera channels [67,68], or a liquid crystal tunable filter [69]. The ratio between $\mathrm{OD}_{\mathrm{Ves}}$ in the two wavelengths, $\mathrm{OD}_{\mathrm{Ves} 1} / \mathrm{OD}_{\mathrm{Ves} 2}$, is the measured parameter, from which the oxygen saturation is derived, assuming a linear relationship between the $\mathrm{OD}_{\mathrm{Ves} 1} / \mathrm{OD}_{\mathrm{Ves} 2}$ and $\mathrm{SO}_{2}$ (either $\mathrm{SaO}_{2}$ or $\mathrm{SvO}_{2}$ ),

$$
\mathrm{SO}_{2}=\mathrm{a}+\mathrm{k}\left(\mathrm{OD}_{\mathrm{Ves} 1} / \mathrm{OD}_{\mathrm{Ves} 2}\right) \text {. }
$$

a and $\mathrm{k}$ are constants that were determined by calibration, in which $\mathrm{SO}_{2}$ was measured in systemic arteries by a pulse oximeter, simultaneously with the retinal arteries examination, during varied hypoxia levels, obtained by breathing different oxygen concentrations [65]. In other studies $[66,67]$, these constants were determined by comparing $\mathrm{OD}_{\mathrm{Ves} 1} / \mathrm{OD}_{\mathrm{Ves} 2}$ values in retinal arteries or veins to the mean of retinal $\mathrm{SaO}_{2}$ or $\mathrm{SvO}_{2}$ data, obtained in former studies [18,20]. Here, the ratio $\mathrm{OD}_{\mathrm{Ves} 1} / \mathrm{OD}_{\mathrm{Ves} 2}$ plays the same role as the ratio-of-ratios $\mathrm{R}$ in pulse oximetry (See Equations (8), (9) and (11)).

One of the two wavelengths in the visible region that are used in retinal oximetry is a wavelength in which the $\mathrm{dHb}$ and $\mathrm{HbO}_{2}$ extinction coefficients have a large difference, such as 600, 610 or 555 $\mathrm{nm}$, and the other is 548 or $570 \mathrm{~nm}[67,68,70]$, an isosbestic wavelength in the 500-600 nm range [19]. In a number of studies [18-20], retinal $\mathrm{SO}_{2}$ was obtained by measuring scattered/reflected light with three wavelengths in the visible region, making use of the method of Pittman and Duling [16], which was mentioned in Section 3.1.

\section{Accuracy and Applications}

The accuracy of retinal oximetry can be evaluated by comparing $\mathrm{SaO}_{2}$ values, measured in retinal arteries, to systemic $\mathrm{SaO}_{2}$ values, measured in the peripheral arteries either noninvasively by pulse oximetry or by co-oximeter in extracted arterial blood. The comparison is based on the assumption that $\mathrm{SaO}_{2}$ is constant throughout the entire systemic arterial system, as oxygen diffuses from blood vessels into tissue only in the capillaries.

Comparison of retinal $\mathrm{SaO}_{2}$ readings to systemic $\mathrm{SaO}_{2}$ values was primarily done with two commercial retinal oximeters: The Dynamic Vessel Analyzer (DVA, Imedos, Jena, Germany) and the Oxymap (Oxymap, Reykjavik, Iceland). The mean of the retinal $\mathrm{SaO}_{2}$ readings by Oxymap, measured in healthy persons, was lower by $5 \%$ than finger $\mathrm{SaO}_{2}$, measured by pulse oximetry, with $95 \% \mathrm{CI}$ of -2 to $12 \%$ [71]. Measurements of mean retinal $\mathrm{SaO}_{2}$ in patients with systemic hypoxemia were lower by $2 \%$ with $95 \% \mathrm{CI}$ of -3 to $11 \%$ compared to invasive femoral $\mathrm{SaO}_{2}$ values [72]. No significant correlation was found between individual retinal and finger $\mathrm{SpO}_{2}$ [72-74]. In a study performed with the DVA retinal oximeter on chronic obstructive pulmonary disease (COPD) patients [75], a low correlation ( $\mathrm{r}=0.6, p<0.05)$ was found between retinal and finger $\mathrm{SpO}_{2}$ readings, and a Bland-Altman plot, comparing retinal and finger $\mathrm{SpO}_{2}$ data, yielded $1.96 \mathrm{SD}$ of $\pm 10 \%$. Told et al. [76] found that the individual retinal $\mathrm{SaO}_{2}$ readings, measured by the DVA and Oxymap retinal oximeters, were significantly different.

The lower mean retinal $\mathrm{SaO}_{2}$, relative to finger $\mathrm{SpO}_{2}$, was explained by an error in the process of the retinal oximeters' calibration or by the countercurrent exchange of oxygen by diffusion from the arteries within the optic nerve $[70,76,77]$. The low value of retinal $\mathrm{SaO}_{2}$ can also be attributed to the 
measurement of $\mathrm{I}_{0 \mathrm{n}}$, the scattered light from the blood vessel neighborhood, which might be affected by light absorption in retinal blood vessels (See Figure 5).

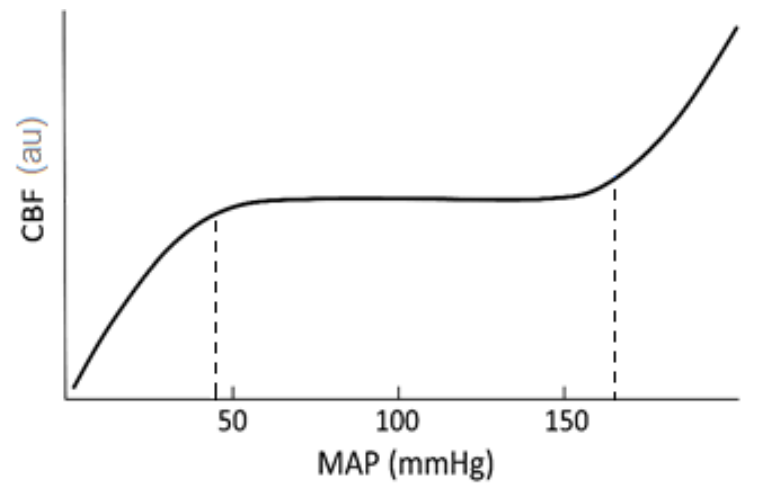

Figure 5. Schematic presentation of the relationship between cerebral blood flow CBF and mean arterial pressure MAP, affected by autoregulation. The autoregulation is only effective between two MAP limits, presented by dashed lines. For MAP lower than the left limit, the brain tissue is ischemic, and for MAP greater than the right limit, the brain tissue is hyperemic, potentially leading to edema with its adverse consequences.

The simultaneous measurement of oxygen saturation in a pair of retinal artery and vein can assess the arteriovenous difference of oxygen saturation and oxygen content, $\mathrm{CaO}_{2}-\mathrm{CvO}_{2}$ (See Equation (1)). The latter provides information on the retinal oxygen consumption in the tissue supplied by the artery and drained by the vein, an important parameter, which is related to the metabolism rate of the retinal cells $[78,79]$. The arteriovenous difference of oxygen saturation or oxygen content decreased during breathing of $100 \%$ oxygen relative to breathing air in measurements on healthy subjects [78,80], but was unchanged in COPD patients [75].

Non-invasive retinal oximetry has been used in physiological studies on healthy persons $[68,70,74,78-80]$ and on patients with ophthalmic and a number of systemic diseases $[70,75,81-86]$. The increase in arteriovenous difference of retinal oxygen saturation is generally due to ischemia, while the decrease in that difference might originate from atrophy, which is associated with lower metabolism of retinal cells. Ischemic diseases include diabetes, central retinal vein occlusions, age-related macular degeneration and retinopathy of prematurity. Atrophy-related retinal diseases include glaucoma and retinitis pigmentosa [70].

The accessibility to light of the human retina has been utilized as a window to the brain, as the retina and its optic nerve are considered an extension of the central nervous system, from the anatomic, functional and pathologic aspects [87-89]. Like the brain, the retina has a large demand for oxygen and nutrient supplies [88], and both tissues utilize autoregulation to keep sufficient blood supply [90]. Retinal oxygen saturation has been suggested as a mirror to brain oxygenation. In studies on mild cognitive impairment and multiple sclerosis patients [91,92], retinal arteriovenous oxygen saturation difference was significantly lower than that of healthy persons, which reflects reduced oxygen extraction in the retina, indicating reduced metabolism.

\section{Near Infrared Spectroscopy (NIRS)}

\subsection{NIRS Techniques}

Near infrared spectroscopy (NIRS) is an oximetric technique that provides assessment of the $\mathrm{HbO}_{2}$ and $\mathrm{dHb}$ concentrations ( $\left[\mathrm{HbO}_{2}\right]$ and $[\mathrm{dHb}]$, respectively), and of oxygen saturation in the entire blood in tissue-arterial, venous and capillary. The tissue oxygen saturation, $\mathrm{StO}_{2}$, is also named as the tissue oxygenation index, TOI, or regional oxygen saturation, $\mathrm{rSO}_{2}$. Like other oximetric techniques, NIRS is based on the different absorption spectrum of $\mathrm{HbO}_{2}$ and $\mathrm{dHb}$ and the measurement of light 
attenuation in two or more wavelengths. As an optical technique, it can non-invasively measure oxygenation in muscles and cerebral tissue that are accessible to light, since infrared light can penetrate several centimeters in tissue $[93,94]$. In order to non-invasively assess oxygenation or oxygenation change in the cerebral tissue, light is emitted into the brain through the intact skull and the light transmitted through the cerebral tissue is measured by a detector located $2-4 \mathrm{~cm}$ from the light-source. The greater the distance between a pair of optodes (the light-source/detector pair), the deeper cerebral tissue examined. For a typical differential pathlength factor (DPF, the ratio between mean actual pathlength and optodes-distance) value of 5, a distance between optodes of $2-4 \mathrm{~cm}$ is equivalent to a transmitted light pathlength of 10-20 cm. Because of the long pathlength, the wavelengths utilized in NIRS are in the near infrared region, 700-1000 nm, where light absorption is relatively small, see Figure 1. Wavelengths above $1000 \mathrm{~nm}$ are significantly absorbed by water [95,96].

In the near infrared region, the main absorbers are $\mathrm{HbO}_{2}$ and $\mathrm{dHb}$. The enzyme cytochrome oxidase (CytOx) is also involved in light absorption in cerebral tissue in this wavelength range, but its concentration is much less than the hemoglobin molecules [97]. CytOx is an enzyme in the mitochondrial electron transport chain that synthesizes the adenosine triphosphate (ATP) - the molecule that provides the energy required for cellular metabolism. Since CytOx oxygenated and deoxygenated states differ in their infrared spectrum, NIRS could also be used for the assessment of CytOx oxygenation, but the near-infrared absorption spectra of the two CytOx states overlap those of the hemoglobins, and the concentration of the latter is significantly greater [93,98-101]. Myoglobin is also involved in infrared light absorption in muscle: its oxygenated and deoxygenated spectra are identical to those of hemoglobin $[14,96,102]$, so that muscle oximetry actually measures the oxygenation state of both hemoglobin and myoglobin molecules [14,103]. The evaluation of CytOx concentration and muscle oxygenation are not discussed in the current review.

As claimed in the current review, the primary problem of oximetry is the discrimination between the absorption and scattering effects in the attenuation measurement. The different light absorption for two wavelengths is the signal, while attenuation due to light-loss G and elongation of the path-length $l$ (Equation (3)) is the primary noise. In arterial pulse oximetry the discrimination between the absorption and scattering effects is achieved by measuring the light attenuation difference between the end-diastole and the end-systole, and assuming that the systolic light attenuation change is mainly due to absorption, neglecting attenuation changes due to the scattering (Equations (7) and (8)). In NIRS, reflected/transmitted light intensity is measured as a function of time or distance from the light-source, and the diffusion equation, presented below, is utilized for deriving two equations that enable the determination of the two unknowns, the absorption constant $\mu_{\mathrm{a}}$ and the reduced scattering constant $\mu_{s}{ }^{\prime}$. The diffusion equation enables the derivation of the photon fluence rate $\varphi(r, t)$ that is reflected/transmitted from the medium surface [96,97], provided that the detailed structure and composition of the tissue are given. Since the real tissue structure is complex and unknown, solution of the diffusion equation for a specific tissue is impractical, and a simple model, simulating the real situation, must be used for NIRS measurements.

In general, the model includes light with a narrow cross-section emitted into a semi-infinite homogenous medium that simulates the biological tissue, and a detector that measures the intensity $I_{R}(\rho, t)$ of the reflected light, which is a function of its distance $\rho$ from the light-source and of the time $t$ (if the emitted light is time-dependent). $I_{R}(\rho, t)$ can be obtained by means of the diffusion equation $[96,97,104,105]$ that relates the rate of change of $\varphi(r, t)$ to the absorption and scattering coefficients of the medium and the photon emission source intensity.

Solutions satisfying the diffusion equation for the semi-infinite medium model with uniform absorption and scattering coefficients have been determined for three categories of light intensity dependence on time: short impulse, sinusoidally modulated intensity and constant intensity. For each sort of time-dependence, the corresponding solution of the reflected light intensity $R(\rho, t)$ is related to the absorption constant, $\mu_{\mathrm{a}}$, and the reduced scattering coefficient, $\mu_{\mathrm{s}}{ }^{\prime}$. In accordance with the different time-dependences of the illumination, three modalities of NIRS have been developed, 
sorted as constant intensity (CW) spatially-resolved, time-resolved or frequency-resolved spectroscopy, where each modality makes use of the dependence of $R(\rho, t)$ on the light source-detector distance, temporal dispersion of short light pulse or phase change of high-frequency intensity-modulated light, respectively $[96,97,106]$.

Time-resolved spectroscopy is based on a short impulse emitted into a tissue volume and scattered from the tissue as a broadened pulse, due to different pathlengths between light entrance and exit for different photons. Since the speed of light in tissue is about $2 \times 10^{10} \mathrm{~cm} / \mathrm{s}$, the time-of-flight of a photon for typical pathlengths of 2 to $10 \mathrm{~cm}$ is 100 to 500 picoseconds. In practice, the short impulse used in time-resolved spectroscopy has a width of a few picoseconds and the broadened reflected pulse demonstrates a time-width of several hundred picoseconds. For the semi-infinite medium model, a solution of the diffusion equation $R(\rho, t)$ can be obtained $[96,104,106,107]$, providing relationship between $R(\rho, t)$ and $\mu_{s}^{\prime}$ and $\mu_{\mathrm{a}}$. By fitting the theoretical solution to the dependence-on-time of the measured reflected light, $\mu_{\mathrm{s}}{ }^{\prime}$ and $\mu_{\mathrm{a}}$ can be determined.

In the frequency-resolved spectroscopy $\mu_{\mathrm{s}}{ }^{\prime}$ and $\mu_{\mathrm{a}}$ can also be determined by solving the diffusion equation for the sinusoidal illumination function. The two unknowns, $\mu_{\mathrm{s}}{ }^{\prime}$ and $\mu_{\mathrm{a}}$, can be derived from the amplitude modulation and the phase shift of the reflected light, obtained from the diffusion equation solution $[104,106]$. Typical values of the modulated light frequency in frequency-resolved spectroscopy are $300-400 \mathrm{MHz}$.

NIRS measurement of blood oxygenation in the brain is based on light scattering from relatively deep tissue, $1-2 \mathrm{~cm}$ below the surface, which necessitates a source-detector distance of $2-4 \mathrm{~cm}$, corresponding to a pathlength of $10-20 \mathrm{~cm}$. Because the light irradiation level into the brain is limited, the transmitted/reflected light has a low intensity and very sensitive detectors must be used. Considering the high time-resolution that is required in the time- and frequency-resolved NIRS for measuring the broadening of the ultrashort pulses or the phase-shift of the very high frequency irradiation, sophisticated techniques of elevated cost must be used. However, sustained technological progress is expected to reduce the costs of the sophisticated time- and frequency-resolved NIRS devices.

In the CW spatially-resolved spectroscopy, reflected light in several wavelengths is measured in several light-sources/detector distances. The solution of the diffusion equation for the semi-infinite medium model relates $R(\rho)$ to some function of the two unknowns, $\mu_{\mathrm{a}}$ and $\mu_{\mathrm{s}}^{\prime}$, and in order to obtain $\mu_{\mathrm{a}}$ separately, several equations have been proposed $[96,97,107,108]$. By applying the diffusion equation in two wavelengths, two equations for $\mu_{\mathrm{a}}(\lambda)$ at two wavelengths can be determined and $\left[\mathrm{HbO}_{2}\right]$ and $[\mathrm{dHb}]$ can be derived from the two equations, based on Equation (4):

$$
\varepsilon \mathrm{C}=\mu_{\mathrm{a}}(\lambda)=\varepsilon_{\mathrm{O}}(\lambda)\left[\mathrm{HbO}_{2}\right]+\varepsilon_{\mathrm{D}}(\lambda)[\mathrm{dHb}]
$$

The tissue oxygen saturation, $\mathrm{StO}_{2}$, can be determined from the $\left[\mathrm{HbO}_{2}\right]$ and $[\mathrm{dHb}]$ values, as $\mathrm{StO}_{2}$ $=\left[\mathrm{HbO}_{2}\right] /\left(\left[\mathrm{HbO}_{2}\right]+[\mathrm{dHb}]\right)$.

$\mathrm{StO}_{2}$ can also be obtained by the spatially-resolved NIRS by differentiating the diffusion equation with respect to $\rho$, which provides a relationship between the gradient of $R(\rho)$ and $\mu_{\mathrm{a}} \mu_{\mathrm{s}}{ }^{\prime}[96,107-110]$. Since $\mu_{\mathrm{a}}=\varepsilon \mathrm{C}$

$$
\mu_{\mathrm{a}} \mu_{\mathrm{s}}{ }^{\prime}=\mu_{\mathrm{s}}{ }^{\prime} \varepsilon \mathrm{C}=\varepsilon_{\mathrm{O}} \mathrm{StO}_{2} \mu_{\mathrm{s}}{ }^{\prime} \mathrm{C}+\varepsilon_{\mathrm{D}}\left(1-\mathrm{StO}_{2}\right) \mu_{\mathrm{s}}{ }^{\prime} \mathrm{C},
$$

See Equation (19). Measuring $\mu_{\mathrm{a}} \mu_{\mathrm{s}}{ }^{\prime}$ with two wavelengths and assuming that the difference in $C$ between the two wavelengths is negligible and that $\mu_{s}$ ' decreases slightly and linearly with the wavelength $[107,110], \mathrm{StO}_{2}$ can be derived from Equation (20) in two wavelengths, using an algorithm that is similar to that for $\mathrm{SaO}_{2}$ measurement by pulse oximetry, see Equations (7) and (8).

The accuracy of the NIRS techniques has been challenged on theoretical grounds, as the solution of the diffusion equation is based on a simplistic homogeneous semi-infinite medium model. The model does not reflect the real complex cerebral tissue structure, covered by cerebral-spinal fluid and bone, which also varies between subjects [96,97,111,112]. Fantini et al. [105] also raised an argument against the applicability of the diffusion equation to the semi-infinite model that simulates the 
tissue in noninvasive NIRS measurements, where the light-source and the detector are placed on the skin surface. The diffusion equation is an approximation that is only appropriate for measurements performed deep inside the bulk medium [105,113].

$\mathrm{StO}_{2}$ was also obtained by means of a single light-source/detector distance, making use of the modified Beer-Lambert equation (Equation (3)) in two or more wavelengths, without utilizing the diffusion equation and the semi-infinite medium model. In that technique, the scattering light-loss $\mathrm{G}$ and the absorption by skin blood and pigmentation are not canceled out and the cerebral $\mathrm{StO}_{2}$ is obtained by calibration with saturation measurements in the jugular vein and arterial blood [114-116]. The calibration of the cerebral $\mathrm{StO}_{2}$, which is a composite of oxygen saturation in arterial and venous blood, is based on the following assumptions: the venous blood oxygen saturation in a cerebral site is equal to that of the jugular vein, which drains blood from that cerebral site; the saturation in cerebral arterial blood is equal to that of the systemic arterial blood; the arterial blood to venous blood proportion in the cerebral tissue is a known ratio (30:70 or 25:75).

NIRS devices with a single light-source/detector distance are sensitive to the interference of extracerebral blood, while multi-distance NIRS devices can remove contamination from the extra-cranial circulation $[117,118]$. Some commercial devices only use a single pair of optodes separated by a distance of about $40 \mathrm{~mm}$, which measures absorption in both cerebral and extracranial tissue, but adds measurement at a distance of about $20 \mathrm{~mm}$, which aims to subtract the absorption signal of the extracranial tissue from the former absorption measurement. Measurements of cerebral StO $\mathrm{O}_{2}$ by three commercial NIRS devices, with different values of extracerebral tissue perfusion (exploiting scalp ischemia), showed that the spatial resolved technique was not effective in isolating the absorption in the cerebral tissue [119].

Constant intensity illumination with a single light-source/detector distance was also used for measuring changes in tissue oxygenation by making use of the modified Beer-Lambert law (Equation (3)) and avoiding the use of the diffusion equation and the semi-infinite medium model. Temporal changes in $\left[\mathrm{HbO}_{2}\right]$ and $[\mathrm{dHb}]$, induced by functional task, such as respiration or venous or arterial occlusion, can be derived from the corresponding temporal changes in light attenuation $[96,97,101,107,120,121]$, assuming that the effect of light-loss G by scattering is the same for the two states and the attenuation difference between the two states substantially originated from absorption. The process of quantitative assessment of $\Delta\left[\mathrm{HbO}_{2}\right]$ and $\Delta[\mathrm{dHb}]$ from the difference between the transmitted/reflected light intensity in the two states, $\mathrm{I}_{1}$ and $\mathrm{I}_{2}$, is similar to that of $\mathrm{SaO}_{2}$ measurement by pulse oximetry (See Equations (7) and (8)):

$$
\ln \left(\mathrm{I}_{1} / \mathrm{I}_{2}\right)=\varepsilon \Delta \mathrm{Cl}=\left(\varepsilon_{\mathrm{O}} \Delta\left[\mathrm{HbO}_{2}\right]+\varepsilon_{\mathrm{D}} \Delta[\mathrm{dHb}]\right) l .
$$

Measurement of $\ln \left(\mathrm{I}_{1} / \mathrm{I}_{2}\right)$ in two wavelengths provides two equations with two unknowns, $\Delta\left[\mathrm{HbO}_{2}\right]$ and $\Delta[\mathrm{dHb}]$, that can be solved for the two unknowns. The pathlength $l$ for the two wavelengths can be obtained from the distance between the two optodes and the differential pathlength factor DPF. The DPF has been determined from time-resolved NIRS or by measuring the mean time-of-flight of ultrashort pulses of light propagating through the tissue $[96,97,107,112,122]$, but since the variability among patients is large $[96,120]$, the measurement accuracy is low. Nevertheless, qualitative information on temporal changes of $\left[\mathrm{HbO}_{2}\right]$ and $[\mathrm{dHb}]$ due to functional tasks is commonly used in functional NIRS (fNIRS).

Cerebral fNIRS measures temporal changes of infrared light intensity transmitted through the brain, yielding temporal changes of $\left[\mathrm{HbO}_{2}\right]$ and $[\mathrm{dHb}]$ in the cerebral tissue that follow functional tasks. The latter is originated from cerebral neural activity that results in a local increase in tissue metabolism and oxygen consumption, followed by vasodilatation and increased blood flow (neurovascular coupling) [123-127].

In cerebral fNIRS, one or a number of non-invasive skull probes are used to evaluate the increase in brain activity at specific locations in the cerebral cortex. Functional near infrared imaging (fNIRI) refers to the simultaneous measurement of local temporal oxygenation changes in multiple sites in a 
large area. In fNIRS and fNIRI, CW NIRS devices are commonly used, due to their small size, suitable time resolution and low-cost, despite the inability of the technique to quantify changes in $\left[\mathrm{HbO}_{2}\right]$ and $[\mathrm{dHb}]$ in absolute terms. The determination of the brain activity location by fNIRS and fNIRI is of low spatial resolution (as compared to other brain imaging modalities, such as fMRI), because of the strong scattering of light in tissue and the long pathlength in NIRS [125,126].

Multi-channel NIRS, followed by image reconstruction, provides a two-dimensional image of the cerebral oxygenation level. A further advancement of fNIRI is the three-dimensional presentation of the cerebral oxygenation-diffuse optical tomography (DOT), which includes the ability to measure light after transmission through several overlapping light-source/detector distances, in each of the multiple sensors. The assessment of the oxygenation dependence on tissue depth is based on the fact that greater distance between the optodes is associated with deeper tissue pathlengths [125-127]. The limited number of light-sources and detectors sets a trade-off between resolution and measurement region area. DOT measurements on the whole cerebral cortex, with relatively high resolution, have been performed on newborns and infants, primarily for neurodevelopmental assessment and detection of neurodevelopmental disorders [126,128-130].

\subsection{Validation and Accuracy}

At present, the primary implementation of NIRS, in both clinical diagnosis and research, is in the assessment of tissue oxygenation in cerebral tissue, which is directly related to cerebral blood perfusion [131-134]. Timely assessment of the latter is important in critically ill patients and patients undergoing major surgical operations, because of their increased incidence of adverse outcomes, particularly neurological complications that may occur due to cerebral hypo-perfusion. Hence, a reliable noninvasive technique for $\mathrm{StO}_{2}$ assessment is expected to be beneficial for the improvement of patient treatment and outcomes in perioperative and intensive care medicine.

A major difficulty of validating the cerebral oxygenation NIRS technology is the absence of acceptable and reliable methods for the measurement of cerebral tissue oxygenation to compare NIRS with [135]. In several studies, NIRS-derived cerebral $\mathrm{StO}_{2}$ readings were compared to oxygen saturation in the jugular vein $\left(\mathrm{SjO}_{2}\right)$, which drains venous blood from one of the brain hemispheres. Both NIRS $\mathrm{StO}_{2}$ and invasive $\mathrm{SjO}_{2}$ decreased during induced hypoxia, though the deviations between the values of the two parameters were significant $[100,135]$. In the study of Rosenthal et al. [136], NIRS $\mathrm{StO}_{2}$ correlated with $\mathrm{SjO}_{2}$ when the latter was measured in blood drained from the hemisphere with the NIRS probe site $(\mathrm{r}=0.60, p<0.001)$, but not with $\mathrm{SjO}_{2}$ measured in the jugular vein that drains blood from the contralateral hemisphere.

As $\mathrm{StO}_{2}$ is the mean oxygen saturation in the entire blood in tissue, arterial and venous, cerebral $\mathrm{StO}_{2}$ readings were compared to a weighted mean of oxygen saturation in blood extracted from the jugular vein and a systemic artery $\left(\mathrm{SavO}_{2}\right)[114,115,135]$, and the comparison rendered smaller deviations than those found for $\mathrm{SjO}_{2}$. The weight of the cerebral arterial and venous blood is generally based on the assumption that the venous-to-arterial blood volume ratio of the cerebral tissue is 70:30, as was found by PET measurements [137]:

$$
\mathrm{SavO}_{2}=0.3 \mathrm{SaO}_{2}+0.7 \mathrm{SjO}_{2}
$$

$\mathrm{SaO}_{2}$ is generally measured by pulse oximetry or by extracting blood from an artery utilizing a co-oximeter; $\mathrm{SjO}_{2}$ is measured invasively by means of a co-oximeter in extracted blood from a jugular vein.

Validation studies of commercial cerebral oximeters were performed on healthy volunteers or patients with jugular catheterization, after calibrating $\mathrm{NIRS} \mathrm{StO}_{2}$, by invasive measurements of $\mathrm{SavO}_{2}$ on a different group of healthy volunteers. In these studies [114-116,138-140], the $\mathrm{StO}_{2} / \mathrm{SavO}_{2}$ correlation coefficient values were $0.7-0.9$, the bias values (mean difference between their individual values) were $0.5-1.2 \%$, and the standard deviation values were $3-5.4 \%$. 
Bickler et al. [100] compared cerebral $\mathrm{StO}_{2}$, measured in healthy volunteers by five commercial cerebral oximeters, with invasive $\mathrm{SavO}_{2}$ during induced hypoxemia. The mean bias values for the different devices were -1.13-2.84 and the standard deviation was 3.92 for one of the devices and 6.27-9.72 for the others. While the cerebral oximeters were found to be effective in detecting the induced desaturations, the significant variation in baseline readings among the five devices demonstrated inaccuracy in absolute cerebral $\mathrm{StO}_{2}$ measurement by the current NIRS devices. Furthermore, the great variation in cerebral $\mathrm{StO}_{2}$ values among the healthy subjects limits the ability of the current non-invasive cerebral oximeters to yield a definite threshold value of the cerebral $\mathrm{StO}_{2}$ that might lead to tissue damage [100].

La Cour et al. [135] reviewed available in vivo validation studies, which compared noninvasive cerebral NIRS-based $\mathrm{StO}_{2}$ to $\mathrm{SavO}_{2}$ in pediatric and adult populations, and found poor agreement in both adults and children: the difference between the limits-of-agreement values was of about $13 \%$. (The limits-of-agreement are the mean of the differences between the two parameters \pm 1.96 standard-deviations). A comparison of $\mathrm{StO}_{2}$ to $\mathrm{SjO}_{2}$ rendered lower agreement: the difference between the limits-of-agreement was about $18 \%$. The poor agreement between cerebral $\mathrm{StO}_{2}$ and $\mathrm{SavO}_{2}$ can be attributed to differences of the arterial-to-venous blood-volume ratio between subjects and differences within subjects, due to changes in hypoxia level. In addition, the jugular vein drains blood from the whole brain hemisphere, while the non-invasive NIRS only measures saturation in the cerebral tissue, and $\mathrm{StO}_{2}$ in the cerebral and non-cerebral tissues are not necessarily equal $[100,135]$.

The partial pressure of oxygen in a tissue $\left(\mathrm{PtO}_{2}\right)$ is a physiological parameter that is related to $\mathrm{StO}_{2}$ through the oxygen-hemoglobin dissociation curve. Cerebral $\mathrm{PtO}_{2}$ is measured invasively in the brain tissue of patients with traumatic brain injury for clinical purposes, and in a number of studies, its association with cerebral $\mathrm{StO}_{2}$ was examined. Despite the relationship of both parameters to the balance between tissue oxygen delivery and consumption, only poor or no correlation between cerebral $\mathrm{StO}_{2}$ and $\mathrm{PtO}_{2}$ was found $[117,118,141,142]$, probably because of the nonlinear relationship between $\mathrm{StO}_{2}$ and $\mathrm{PtO}_{2}$ in the blood (the oxygen-hemoglobin dissociation curve).

The precision of NIRS devices, i.e., the variation of repeated measurements at the same site, was also evaluated in a number of studies on neonates, rendering values of $5.2 \%$ [111] and $2.0 \%$ on term and $4.2 \%$ on preterm neonates [143]. In a recent study [144] on preterm neonates, a precision value of $2.64 \%$ was found, but some part of the $\mathrm{StO}_{2}$ variability was attributed to spontaneous hemodynamic fluctuations. Using methods for reducing the fluctuations' effect, an improved precision value of $1.85 \%$ was achieved.

The validation studies dealt with in the current subsection, and evaluated the accuracy of cerebral $\mathrm{StO}_{2}$ readings measured in absolute terms by NIRS cerebral oximeters, based on CW spatially-resolved spectroscopy and calibration by invasive $\mathrm{SjO}_{2}$ measurements. In those studies, the accuracy of the commercial devices based on the NIRS technique was found to be low, and the inter-subject and inter-device deviations were substantial. Nevertheless, qualitative information on cerebral $\mathrm{StO}_{2} \mathrm{can}$ be obtained by NIRS, and changes in cerebral $\mathrm{StO}_{2}$ as a function of time can be detected reliably, as will be described in the following subsection.

\subsection{Clinical Applications}

The potential benefit of NIRS cerebral $\mathrm{StO}_{2}$ readings for clinical treatment has been evaluated in a number of studies, in particular in randomized intervention studies on patients undergoing major surgical operations. In the latter studies, in the intervention group, cerebral $\mathrm{StO}_{2}$ was monitored during the surgical operation by NIRS, and supplemental oxygen dosage was adjusted according to $\mathrm{StO}_{2}$ level, while in the control group, the treatment was not directed by NIRS readings. In several studies, the intervention group demonstrated a decreased incidence of adverse events compared with the control group [145-147], while in similar studies [148-150], the NIRS-guided intervention was not associated with improved patient outcomes. Yu et al. [151], in a systematic review, inferred low quality 
of evidence for the beneficial effect of cerebral NIRS monitoring on postoperative adverse events, such as stroke, delirium or death, due to a low number of events and wide confidence intervals.

The benefit of NIRS cerebral $\mathrm{StO}_{2}$ measurements for clinical treatment in preterm neonates has also been evaluated in a randomized intervention clinical trial, performed in eight neonatal intensive care units [152-154]. In the intervention group, the burden of hypoxia was significantly lower than that in the control group, but no decrease was found in all-cause mortality, brain injury score and other clinical outcomes $[152,153]$. No difference in neurodevelopment outcomes at two years of corrected age was found between the two groups [154].

In observational studies, decreased perioperative cerebral $\mathrm{StO}_{2}$ was associated with poor patient outcomes after a major surgery [155,156]. In a recent systematic review [133], an association between low cerebral $\mathrm{StO}_{2}$ and higher incidence of delirium was found in four studies in critically ill patients, compared to controls [157-160], but only in two of them [159,160] was the relationship statistically significant.

Continuous assessment of brain tissue blood flow and oxygenation of brain tissue is clinically important for traumatic brain injury (TBI) patients, for whom rapid diagnosis is essential for the timely restoration of brain metabolic function and the avoidance of secondary brain injury. In order to identify episodes of cerebral ischemia and hypoxia that can deteriorate patients' clinical state, several invasive techniques are being used to measure physiological markers, such as intracranial pressure and $\mathrm{PtO}_{2}$. The opportunity to replace those invasive modalities with noninvasive ones has motivated observational studies that examined the association of CW NIRS $\mathrm{StO}_{2}$ monitoring in adult TBI patients with their functional outcome and with physiological-neurological parameters $[117,118,161]$. Several studies showed that the detection and evaluation of cerebral hypoxia by NIRS were related to increased mortality or poor functional outcome, but the evidence was relatively weak, and additional research is needed before NIRS-based techniques are routinely utilized as a reliable clinical tool.

An interesting application of $\mathrm{NIRS} \mathrm{StO}_{2}$ monitoring is the assessment of cerebral autoregulation (CAR) - the ability of the brain to keep cerebral blood flow (CBF) relatively constant during changes of mean arterial blood pressure, as long as the latter is maintained within defined limits (Figure 5) [162-164]. CAR protects the brain from hypo-perfusion caused by low perfusion-pressure and from hypertension episodes that can lead to elevated intracranial pressure and to damage to the micro-vessels. In adverse events such as traumatic brain injury, the CAR mechanism might be compromised, potentially leading to an exacerbation of the patient's condition. Evaluation of CAR can be done from the relationship between the temporal changes in CBF and those in mean arterial blood pressure (MAP) - a positive correlation between them indicates impaired CAR, while intact autoregulation leads to a low correlation [118]. However, since CBF cannot be measured directly, surrogate parameters are being used, such as intra-cranial pressure, measured invasively, or trans-cranial Doppler velocity, measured in the middle cerebral artery. A number of quantitative CAR indices, based on those surrogate measurements of CBF, have been developed for CAR assessment [165]. Cerebral NIRS-derived $\mathrm{StO}_{2}$ has also been used as a surrogate for spontaneous CBF changes, as tissue oxygenation is directly

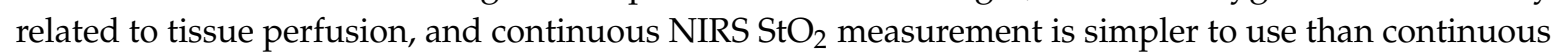
trans-cranial Doppler measurement.

NIRS-derived CAR indices have been compared to those based on trans-cranial Doppler monitoring, and correlation values of $0.40-0.81$ were found between indices obtained by the two methods $[117,118,166-170]$. In a study performed on children during cardiopulmonary bypass [171], high values of the NIRS-derived CAR index were associated with hypotension. The latter study also found that the lower MAP limit of the CAR curve (Figure 5) can be determined from the NIRS CAR index.

The correlation between the two sets of CAR indices, obtained by trans-cranial Doppler velocimetry and by NIRS, is significant but low, and only allows validation in qualitative terms of the NIRS-based CAR assessment. As was described above, validation studies of the cerebral oximeters reported low 
accuracy of the technique and substantial inter-subject and inter-device deviations when $\mathrm{StO}_{2}$ readings were measured in absolute terms, while changes of cerebral $\mathrm{StO}_{2}$ can be obtained qualitatively.

The review was focused on oximetric measurements on humans, but cerebral oxygenation has also been measured by NIRS and fNIRS on animals, both for physiological and pathological animal research and for the assessment of the techniques. Some references [172-176], not representative of studies describing cerebral NIRS and fNIRS measurements on animals, were presented.

\section{Conclusions}

Due to the paramount physiological importance of adequate oxygen supply to the tissue, clinical evaluation of blood oxygenation in arteries and veins is essential, motivating the development of clinical techniques for the measurement and monitoring of blood oxygenation in arteries, in veins or in both arteries and veins in the tissue. The non-invasive nature of light propagation through tissue and the different spectra of oxygenated and deoxygenated hemoglobin stimulated the development of several oximetric techniques for the assessment of oxygen saturation and concentrations of oxygenated and deoxygenated hemoglobin, parameters that provide information on blood oxygenation. The current review presents the main oximetric techniques for the assessment of blood oxygenation by measurements of attenuation in tissue of light comprising two wavelengths, utilizing the different absorption spectra of oxygenated and deoxygenated hemoglobin. The various oximetric techniques enable the evaluation of oxygenation in arterial or venous blood or in the entire blood in tissue, in finger, peripheral muscle, brain or retina-tissues that are accessible to light in the visible or infrared regions.

The primary challenge of oximetry is the discrimination between the effects of absorption by hemoglobin (signal) and scattering by tissue elements (noise) in the attenuation process, and several mechanisms have been created to isolate the absorption effect. Currently, only two techniques, pulse oximetry for the measurement of oxygen saturation in arterial blood, and NIRS, for the assessment of tissue oxygenation in cerebral and muscle tissue, are being used in clinical practice, and only pulse oximetry has been widely accepted as a valid diagnostic tool. The use of photoplethysmography, for the isolation of absorption in arterial blood, enabled pulse oximetry to provide arterial blood oxygen saturation measurements with reasonable accuracy. The accuracy of pulse oximetry seems to be sufficient for most clinical requirements, though in patients under oxygen supplementation, preterm neonates in particular, greater accuracy is required to avoid excessive oxygenation. In regard to NIRS, it seems that significant improvement in its technical aspects is required in order to obtain reliable absolute measurement of cerebral oxygen saturation, a prerequisite for a medical device to be widely accepted as a clinical tool.

Author Contributions: M.N. conceptualized and wrote the review. I.N. and Y.A. critically reviewed it. All authors have read and agreed to the published version of the manuscript.

Funding: This research received no external funding.

Conflicts of Interest: The authors declare no conflict of interest. 


\section{Abbreviations}

$\mathrm{CaO}_{2} \quad$ oxygen content in arterial blood

$[\mathrm{Hb}]$ hemoglobin concentration in blood

$\mathrm{HbO}_{2} \quad$ oxygenated hemoglobin

$\mathrm{dHb} \quad$ deoxygenated hemoglobin

$\mathrm{SO}_{2} \quad$ oxygen saturation in blood vessels, arteries or veins

$\mathrm{SaO}_{2} \quad$ arterial oxygen saturation

$\mathrm{SpO}_{2} \quad$ arterial oxygen saturation measured by pulse oximetry

$\mathrm{PaO}_{2}$ arterial oxygen tension

$\mathrm{SvO}_{2} \quad$ oxygen saturation in venous blood

$\mathrm{StO}_{2} \quad$ oxygen saturation in tissue blood

$\mathrm{SjO}_{2} \quad$ oxygen saturation in the jugular vein

$\mathrm{SavO}_{2} \quad$ weighted mean of oxygen saturation in blood in the jugular vein and in a systemic artery

$\mu_{\mathrm{a}} \quad$ absorption constant

$\mu_{\mathrm{s}} \quad$ scattering coefficient

$\mu_{\mathrm{s}}{ }^{\prime} \quad$ reduced scattering coefficient

$\mathrm{g}$ anisotropy

$\varepsilon_{\mathrm{O}} \quad$ extinction coefficients of $\mathrm{HbO}_{2}$

$\varepsilon_{\mathrm{D}} \quad$ extinction coefficients of $\mathrm{dHb}$

$\varepsilon \quad$ the mean extinction coefficient of blood in the tissue vessels, arteries and veins

C hemoglobin concentration

$\mathrm{I}_{0} \quad$ incident light intensity

$\mathrm{I}_{\mathrm{t}} \quad$ transmitted light intensity

d emitter-detector distance

$l \quad$ mean optical path-length

DPF differential pathlength factor

G light-loss due to tissue scattering

OD optical density

PPG photoplethysmography

$I_{D} \quad$ The maximal value of the PPG pulse

IS The minimal value of the PPG pulse

AC the difference between the maximal and minimal values of the PPG pulse

DC the mean light transmission during the pulse

$\lambda \quad$ wavelengths

$\Delta \mathrm{C}$ the maximal hemoglobin concentration increase in the tissue during systole

$\mathrm{R} \quad$ ratio of ratios

NIRS Near infrared spectroscopy

TOI tissue oxygenation index

$\mathrm{rSO}_{2} \quad$ regional oxygen saturation

CytOx cytochrome oxidase

$I_{R}(\rho, t) \quad$ the intensity of the transmitted/reflected light in NIRS

$\rho$ the distance from the light-source

$\mathrm{t} \quad$ time

CW constant wave/intensity

fNIRS functional NIRS

fNIRI functional near infrared imaging

DOT diffuse optical tomography

$\mathrm{PtO}_{2} \quad$ oxygen partial pressure in a tissue

TBI traumatic brain injury

CAR cerebral autoregulation

CBF cerebral blood flow

MAP mean arterial blood pressure 


\section{References}

1. Plötz, F.B.; van Lingen, R.A.; Bos, A.P. Venous oxygen measurements in the inferior vena cava in neonates with respiratory failure. Crit. Care 1998, 2, 57-60. [CrossRef] [PubMed]

2. Osypka, M.; Soleymani, S.; Seri, I.; Noori, S. Assessment of Cardiac output in neonates: Techniques using the Fick principle, pulse wave analysis and electrical impedance. In Hemodynamics and Cardiology: Neonatology Questions and Controversies, 2nd ed.; Kleinman, C.S., Seri, I., Eds.; Elsevier Saunders: Philadelphia, PA, USA, 2012; Chapter 6; pp. 125-149.

3. Prahl, S. The absorption spectra of the oxygenated and deoxygenated hemoglobin molecules. Available online: http://omlc.ogi.edu/spectra/hemoglobin/index.html (accessed on 21 January 2014).

4. Zuzak, K.J.; Schaeberle, M.D.; Gladwin, M.T.; Cannon, R.O., 3rd; Levin, I.W. Noninvasive Determination of Spatially Resolved and Time-Resolved Tissue Perfusion in Humans During Nitric Oxide Inhibition and Inhalation by Use of a Visible-Reflectance Hyperspectral Imaging Technique. Circulation 2001, 104, 2905-2910. [CrossRef] [PubMed]

5. Greenman, R.L.; Panasyuk, S.; Wang, X.; Lyons, T.E.; Dinh, T.; Longoria, L.; Giurini, J.M.; Freeman, J.; Khaodhiar, L.; Veves, A. Early Changes in the Skin Microcirculation and Muscle Metabolism of the Diabetic Foot. Lancet 2005, 366, 1711-1717. [CrossRef]

6. Benaron, D.A.; Parachikov, I.H.; Cheong, W.F.; Friedland, S.; Rubinsky, B.E.; Otten, D.M.; Liu, F.W.H.; Levinson, C.J.; Murphy, A.L.; Price, J.W.; et al. Design of a visible-light spectroscopy clinical tissue oximeter. J. Biomed. Opt. 2005, 10, 44005. [CrossRef]

7. Van Noord, D.; Sana, A.; Benaron, D.A.; Pattynama, P.M.T.; Verhagen, H.J.M.; Hansen, B.E.; Kuipers, E.J.; Mensink, P.B.F. Endoscopic visible light spectroscopy: A new, minimally invasive technique to diagnose chronic GI ischemia. Gastrointest. Endosc. 2011, 73, 291-298. [CrossRef]

8. Jacques, S.L. Optical properties of biological tissues: A review. Phys. Med. Biol. 2013, 58, R37-R61. [CrossRef]

9. Jonasson, H.; Fredriksson, I.; Bergstrand, S.; Östgren, C.J.; Larsson, M.; Strömberg, T. In vivo characterization of light scattering properties of human skin in the 475- to 850-nm wavelength range in a Swedish cohort. J. Biomed. Opt. 2018, 23, 121608. [CrossRef]

10. Friebel, M.; Helfmann, J.; Netz, U.; Meinke, M. Influence of oxygen saturation on the optical scattering properties of human red blood cells in the spectral range 250 to $2000 \mathrm{~nm}$. J. Biomed. Opt. 2009, 14, 034001. [CrossRef]

11. Jacques, S.L. Time-resolved reflectance spectroscopy in turbid tissues. IEEE Trans. Biomed. Eng. 1989, 36, 1155-1161. [CrossRef]

12. Matcher, S.J.; Cooper, C.E. Absolute quantification of deoxyhaemoglobin concentration in tissue near infrared spectroscopy. Phys. Med. Biol. 1994, 39, 1295-1312. [CrossRef]

13. Zijlstra, W.G.; Buursma, A.; Meeuwsen-van der Roest, W.P. Absorption Spectra of Human Fetal and Adult Oxyhemoglobin, De-Oxyhemoglobin, Carboxyhemoglobin, and Methemoglobin. Clin. Chem. 1991, 37, 1633-1638. [CrossRef] [PubMed]

14. Barstow, T.J. Understanding near infrared spectroscopy and its application to skeletal muscle research. J. Appl. Physiol. 2019, 126, 1360-1376. [CrossRef] [PubMed]

15. Twersky, V. Interface effects in multiple scattering by large, low-refracting, absorbing particles. J. Opt. Soc. Am. 1970, 60, 908-914. [CrossRef]

16. Pittman, R.N.; Duling, B.R. A new method for the measurement of percent oxyhemoglobin. J. Appl. Physiol. 1975, 38, 315-320. [CrossRef]

17. Iwasaki, H.; Yoshizaki, K.; Koyano, H. Fiber-optic transmission catheter for regional venous oxygen saturation and blood flow. J. Appl. Physiol. 1992, 72, 1616-1621. [CrossRef]

18. Delori, F.C. Noninvasive technique for oximetry of blood in retinal vessels. Appl. Opt. 1988, 27, 1113-1125. [CrossRef]

19. Smith, M.H. Optimum wavelength combinations for retinal vessel oximetry. Appl. Opt. 1999, 38, $258-267$. [CrossRef]

20. Harris, A.; Dinn, R.B.; Kagemann, L.; Rechtman, E. A review of methods for human retinal oximetry. Ophthalmic. Surg. Lasers Imaging 2003, 34, 152-164. [CrossRef]

21. Millikan, G.A. The oximeter: An instrument for measuring continuously oxygen saturation of arterial blood in man. Rev. Sci. Instrum. 1942, 13, 434-444. [CrossRef] 
22. Merrick, E.B.; Hayes, T.J. Continuous, Non-Invasive Measurements of Arterial Blood Oxygen Levels. Hewlett-Packard J. 1976, 28, 2-9. Available online: https://archive.org/details/Hewlett-Packard_Journal_Vol. _28_No._2_1976-10_Hewlett-Packard/page/n1/mode/2up (accessed on 26 August 2020).

23. Saunders, N.A.; Powels, A.C.P.; Rebuck, A.S. Ear Oximetry: Accuracy and Practicability in the Assessment of Arterial Oxygenation. Am. Rev. Respir. Dis. 1976, 113, 745-749.

24. Douglas, N.J.; Brash, H.M.; Wraight, P.K.; Calverley, P.M.A.; Legget, R.J.E.; McElderry, L.; Flenley, D.C. Accuracy, sensitivity to carboxyhemoglobin and speed of response of the Hewlett Packard 47201A ear oximeter. Am. Rev. Respir. Dis. 1979, 119, 311-313. [PubMed]

25. West, P.; George, C.F.; Kryger, M.H. Dynamic in vivo response characteristics of three oximeters: Hewlett-Packard 47201A, Biox III, and Nellcor N-100. Sleep 1987, 10, 263-271. [CrossRef] [PubMed]

26. Severinghaus, J.W. Takuo Aoyagi: Discovery of pulse oximetry. Anesth. Analg. 2007, 105, S1-S4. [CrossRef] [PubMed]

27. Molnar, Z.; Umgelter, A.; Toth, I.; Livingstone, D.; Weyland, A.; Sakka, S.G.; Meier-Hellmann, A. Continuous Monitoring of $\mathrm{ScvO}(2)$ by a New Fibre-Optic Technology Compared With Blood Gas Oximetry in Critically Ill Patients: A Multicentre Study. Intensive Care Med. 2007, 33, 1767-1770. [CrossRef]

28. Iodice, F.G.; Ricci, Z.; Haiberger, R.; Favia, I.; Cogo, P. Fiberoptic monitoring of central venous oxygen saturation (PediaSat) in small children undergoing cardiac surgery: Continuous is not continuous. F1000Research 2014, 3, 23. [CrossRef]

29. Herner, A.; Haller, B.; Mayr, U.; Rasch, S.; Offman, L.; Schmid, R.; Huber, W. Accuracy and precision of $\mathrm{S}_{\mathrm{CV}} \mathrm{O}_{2}$ measured with the CeVOX device: A prospective study in patients with a wide variation of $\mathrm{S}_{\mathrm{CV}} \mathrm{O}_{2}$-values. PLoS ONE 2018, 13, e0192073. [CrossRef]

30. Baulig, W.; Spielmann, N.; Zaiter, H.; Lijovic, T.; Bettex, D.; Bürki, C.; Weiss, M. In-vitro evaluation of the PediaSat continuous central venous oxygenation monitoring system. Eur. J. Anaesthesiol. 2010, 27, $289-294$. [CrossRef]

31. Stocchetti, N.; Magnoni, S.; Zanier, E.R. My paper 20 years later: Cerebral venous oxygen saturation studied with bilateral samples in the internal jugular veins. Intensive Care Med. 2015, 41, 412-417. [CrossRef]

32. Gupta, A.K.; Hutchinson, P.J.; Al-Rawi, P.; Gupta, S.; Swart, M.; Kirkpatrick, P.J.; Menon, D.K.; Datta, A.K. Measuring brain tissue oxygenation compared with jugular venous oxygen saturation for monitoring cerebral oxygenation after traumatic brain injury. Anesth. Analg. 1999, 88, 549-553. [CrossRef]

33. Gopinath, S.P.; Robertson, C.S.; Contant, C.F.; Hayes, C.; Feldman, Z.; Narayan, R.K.; Grossman, R.G. Jugular venous desaturation and outcome after head injury. Neurol. Neurosurg. Psychiatr. 1994, 57, 717-723. [CrossRef]

34. White, H.; Baker, A. Continuous jugular venous oximetry in the neurointensive care unit-A brief review. Can. J. Anaesth. 2002, 49, 623-629. [CrossRef] [PubMed]

35. Schoon, P.; Benito Mori, L.; Orlandi, G.; Larralde, C.; Radrizzan, M. Incidence of intracranial hypertension related to jugular bulb oxygen saturation disturbances in severe traumatic brain injury patients. Acta Neurochir. 2002, 81, 285-287.

36. Yoshiya, I.; Shimada, Y.; Tanake, K. Spectrophotometric monitoring of arterial oxygen saturation on the fingertip. Med. Biol. Eng. Comput. 1980, 18, 27-32. [CrossRef] [PubMed]

37. Wieben, O. Light absorbance in pulse oximetry. In Design of Pulse Oximeters; Webster, J.G., Ed.; Institute of Physics Publishing: Bristol, UK, 1997; pp. 40-55. ISBN 9780750304672.

38. Mannheimer, P.D.; Casciani, J.R.; Fein, M.E.; Nierlich, S.L. Wavelength selection for low-saturation pulse oximetry. IEEE Trans. Biomed. Eng. 1997, 44, 148-158. [CrossRef] [PubMed]

39. Nitzan, M.; Babchenko, A.; Khanokh, B.; Taitelbaum, H. The measurement of oxygen saturation in venous blood by dynamic near IR spectroscopy. J. Biomed. Opt. 2000, 5, 155-162. [CrossRef] [PubMed]

40. Kyriacou, P.A. Pulse oximetry in the esophagus. Physiol. Meas. 2006, 27, R1-R35. [CrossRef]

41. Yossef Hay, O.; Cohen, M.; Nitzan, I.; Kasirer, Y.; Shahroor-Karni, S.; Yitzhaky, Y.; Engelberg, S.; Nitzan, M. Pulse Oximetry with Two Infrared Wavelengths without Calibration in Extracted Arterial Blood. Sensors 2018, 18, 3457. [CrossRef]

42. Kim, J.G.; Liu, H. Variation of haemoglobin extinction coefficients can cause errors in the determination of haemoglobin concentration measured by near-infrared spectroscopy. Phys. Med. Biol. 2007, 52, 6295-6322. [CrossRef] 
43. Kim, J.G.; Liu, H.; (Joint Graduate Program in Biomedical Engineering, University of Texas at Arlington/University of Texas Southwestern Medical Center at Dallas, Arlington, TX 7601, USA). Personal communication, 2007.

44. Zourabian, A.; Siegel, A.; Chance, B.; Ramanujan, N.; Rode, M.; Boas, D.A. Trans-abdominal monitoring of fetal arterial blood oxygenation using pulse oximetry. J. Biomed. Opt. 2000, 5, 391-405. [CrossRef]

45. Schowalter, J.S. Calibration. In Design of Pulse Oximeters; Webster, J.G., Ed.; Institute of Physics Publishing: Bristol, UK, 1997; Chapter 10.

46. Hornberger, C.; Wabnitz, H. Approaches for calibration and validation of near-infrared optical methods for oxygenation monitoring. Biomed. Tech. 2018, 25, 537-546. [CrossRef]

47. Seguin, P.; Le Rouzo, A.; Tanguy, M.; Guillou, Y.M.; Feuillu, A.; Mallédant, Y. Evidence for the need of bedside accuracy of pulse oximetry in an intensive care unit. Crit. Care Med. 2000, 28, 703-706. [CrossRef]

48. Van de Louw, A.; Cracco, C.; Cerf, C.; Harf, A.; Duvaldestin, P.; Lemaire, F.; Brochard, L. Accuracy of pulse oximetry in the intensive care unit. Intensive Care Med. 2001, 27, 1606-1613. [CrossRef] [PubMed]

49. Wilson, B.J.; Cowan, H.J.; Lord, J.A.; Zuege, D.J.; Zygun, D.A. The accuracy of pulse oximetry in emergency department patients with severe sepsis and septic shock: A retrospective cohort study. BMC Emerg. Med. 2010, 10, 9. [CrossRef] [PubMed]

50. Rosychuk, R.J.; Hudson-Mason, A.; Eklund, D.; Lacaze-Masmonteil, T. Discrepancies between arterial oxygen saturation and functional oxygen saturation measured with pulse oximetry in very preterm infants. Neonatology 2012, 101, 14-19. [CrossRef] [PubMed]

51. Ross, P.A.; Newth, C.J.; Khemani, R.G. Accuracy of pulse oximetry in children. Pediatrics 2014, 133, $22-29$. [CrossRef]

52. Lakshminrusimha, S.; Manja, V.; Mathew, B.; Suresh, G.K. Oxygen targeting in preterm infants: A physiological interpretation. J. Perinatol. 2015, 35, 8-15. [CrossRef]

53. Cummings, J.J.; Polin, R.A. Committee on fetus and newborn. Oxygen targeting in extremely low birth weight infants. Pediatrics 2016, 138, e20161576. [CrossRef]

54. Thijssen, M.; Janssen, L.; le Noble, J.; Foudraine, N. Facing $\mathrm{SpO}_{2}$ and $\mathrm{SaO}_{2}$ discrepancies in ICU patients: Is the perfusion index helpful? J. Clin. Monit. Comput. 2019. [CrossRef]

55. SUPPORT Study Group. Target Ranges of Oxygen Saturation in Extremely Preterm Infants. N. Engl. J. Med. 2010, 362, 1959-1969. [CrossRef]

56. BOOST-II Australia and United Kingdom Collaborative Groups; Tarnow-Mordi, W.; Stenson, B.; Kirby, A.; Juszczak, E.; Donoghoe, M.; Deshpande, S.; Morley, C.; King, A.; Doyle, L.W.; et al. Outcomes of Two Trials of Oxygen-Saturation Targets in Preterm Infants. N. Engl. J. Med. 2016, 374, 749-760.

57. Hafner, S.; Beloncle, F.; Koch, A.; Radermacher, P.; Asfar, A. Hyperoxia in intensive care, emergency, and peri-operative medicine: Dr. Jekyll or Mr. Hyde? A 2015 update. Ann. Intensive Care 2015, 5, 42. [CrossRef] [PubMed]

58. Demiselle, J.; Wepler, M.; Hartmann, C.; Radermacher, P.; Schortgen, F.; Meziani, F.; Singer, M.; Seegers, V.; Asfar, P. Hyperoxia toxicity in septic shock patients according to the Sepsis-3 criteria: A post hoc analysis of the HYPER2S trial. Ann. Intensive Care 2018, 8, 90. [CrossRef] [PubMed]

59. Nitzan, M.; Noach, S.; Tobal, E.; Adar, Y.; Miller, Y.; Shalom, E.; Engelberg, S. Calibration-free pulse oximetry based on two wavelengths in the infrared-A preliminary study. Sensors 2014, 14, 7420-7434. [CrossRef] [PubMed]

60. Khan, M.; Pretty, C.G.; Amies, A.C.; Balmer, J.; Banna, H.E.; Shaw, G.M.; Geoffrey Chase, J. Proof of concept non-invasive estimation of peripheral venous oxygen saturation. Biomed. Eng. Online 2017, 16, 60. [CrossRef] [PubMed]

61. Wolf, M.; Due, G.; Keel, M.; Niederer, P.; von Siebenthal, K.; Bucher, H.-U. Continuous noninvasive measurement of cerebral arterial and venous oxygen saturation at the bedside in mechanically ventilated neonates. Crit. Care Med. 1997, 25, 1579-1582. [CrossRef]

62. Walton, Z.D.; Kyriacou, P.A.; Silverman, D.G.; Shelley, K.H. Measuring venous oxygenation using the photoplethysmograph waveform. J. Clin. Monit. Comput. 2010, 24, 295-303. [CrossRef]

63. Duadi, H.; Nitzan, M.; Fixler, D. Simulation of oxygen saturation measurement in a single blood vein. Opt. Lett. 2016, 41, 4312-4315. [CrossRef]

64. Hammer, M.; Leistritz, S.; Leistritz, L.; Schweitzer, D. Light Paths in Retinal Vessel Oxymetry. IEEE Trans. Biomed. Eng. 2001, 48, 592-598. [CrossRef] 
65. Beach, J.M.; Schwenzer, K.J.; Srinivas, S.; Kim, D.; Tiedeman, J.S. Oximetry of retinal vessels by dual wavelength imaging: Calibration and influence of pigmentation. J. Appl. Physiol. 1999, 86, 748-758. [CrossRef]

66. Hardarson, S.H.; Harris, A.; Karlsson, R.; Halldorsson, G.; Kagemann, L.; Rechtman, E.; Zoega, G.M.; Eysteinsson, T.; Benediktsson, J.A.; Thorsteinsson, A.; et al. Automatic Retinal Oximetry. Investig. Ophthalmol. Visual Sci. 2006, 47, 11. [CrossRef]

67. Hammer, M.; Vilser, W.; Riemer, T.; Schweitzer, D. Retinal Vessel Oximetry-Calibration, Compensation for Vessel Diameter and Fundus Pigmentation, and Reproducibility. J. Biomed. Opt. 2008, 13, 054015. [CrossRef] [PubMed]

68. Hammer, M.; Vilser, W.; Riemer, T.; Liemt, F.; Jentsch, S.; Dawczynski, J.; Schweitzer, D. Retinal Venous Oxygen Saturation Increases by Flicker Light Stimulation. IOVS 2011, 52, 1. [CrossRef]

69. Mordant, D.J.; Al-Abboud, I.; Muyo, G.; Gorman, A.; Sallam, A.; Ritchie, P.; Harvey, A.R.; McNaught, A.I. Spectral imaging of the retina. Eye 2011, 25, 309-320. [CrossRef] [PubMed]

70. Stefánsson, E.; Olafsdottir, B.O.; Eliasdottir, T.S.; Wehmeijer, W.; Einarsdottir, A.B.; Bek, T.; Torp, T.L.; Grauslund, J.; Eysteinsson, T.; Karlsson, R.A.; et al. Retinal oximetry: Metabolic imaging for diseases of the retina and brain. Progress Retinal Eye Res. 2019, 70, 1-22. [CrossRef] [PubMed]

71. Traustason, S.; Jensen, A.S.; Arvidsson, H.S.; Munch, I.C.; Søndergaard, L.; Larsen, M. Retinal oxygen saturation in patients with systemic hypoxemia. Investig. Ophthalmol. Vis. Sci. 2011, 52, 5064-5067. [CrossRef]

72. Eliasdottir, T.S.; Bragason, D.; Hardarson, S.H.; Vacchiano, C.; Gislason, T.; Kristjansdottir, J.V.; Kristjansdottir, G.; Stefánsson, E. Retinal oximetry measures systemic hypoxia in central nervous system vessels in chronic obstructive pulmonary disease. PLoS ONE 2017, 12, e0174026. [CrossRef]

73. Geirsdottir, A.; Palsson, O.; Hardarson, S.H.; Olafsdottir, O.B.; Kristjansdottir, J.V.; Stefánsson, E. Retinal vessel oxygen saturation in healthy individuals. Investig. Ophthalmol. Vis. Sci. 2012, 53, 5433-5442. [CrossRef]

74. Yang, W.; Fu, Y.; Dong, Y.; Lin, L.; Huang, X.; Li, Y.; Lin, X.; Gao, Q. Retinal vessel oxygen saturation in a healthy young Chinese population. Acta Ophthalmol. 2016, 94, 373-379. [CrossRef]

75. Palkovits, S.; Lasta, M.; Boltz, A.; Schmidl, D.; Kaya, S.; Hammer, M.; Marzluf, B.; Popa-Cherecheanu, A.; Frantal, S.; Schmetterer, L.; et al. Measurement of retinal oxygen saturation in patients with chronic obstructive pulmonary disease. Investig. Ophthalmol. Vis. Sci. 2013, 54, 1008-1013. [CrossRef]

76. Told, R.; Boltz, A.; Schmetterer, L.; Garh€ofer, G.; Sacu, S.; Schmidt-Erfurth, U.; Pollreisz, A. Method comparison of two non-invasive dual-wavelength spectrophotometric retinal oximeters in healthy young subjects during normoxia. Acta Ophthalmol. 2018, 96, e614-e618. [CrossRef]

77. Eliasdottir, T.S. Retinal oximetry and systemic arterial oxygen levels. Acta Ophthalmol. 2018, 96, 1-44. [CrossRef] [PubMed]

78. Werkmeister, R.M.; Schmidl, D.; Aschinger, G.; Doblhoff-Dier, V.; Palkovits, S.; Wirth, M.; Garhöfer, G.; Linsenmeier, R.A.; Leitgeb, R.A.; Schmetterer, L. Retinal oxygen extraction in humans. Retinal oxygen extraction in humans. Sci. Rep. 2015, 5, 15763. [CrossRef] [PubMed]

79. Bata, A.M.; Fondi, K.; Szegedi, S.; Aschinger, G.C.; Hommer, A.; Schmidl, D.; Chua, J.; Werkmeister, R.M.; Garhöfer, G.; Schmetterer, L. Age-Related Decline of Retinal Oxygen Extraction in Healthy Subjects. Investig. Ophthalmol. Vis. Sci. 2019, 60, 3162-3169. [CrossRef] [PubMed]

80. Olafsdottir, O.B.; Eliasdottir, T.S.; Kristjansdottir, J.V.; Hardarson, S.H.; Stefánsson, E. Retinal Vessel Oxygen Saturation during 100\% Oxygen Breathing in Healthy Individuals. PLoS ONE 2015, 10, e0128780. [CrossRef]

81. Olafsdottir, O.B.; Hardarson, S.H.; Gottfredsdottir, M.S.; Harris, A.; Stefánsson, E. Retinal oximetry in primary open-angle glaucoma. Investig. Ophthalmol. Vis. Sci. 2011, 52, 6409-6413. [CrossRef]

82. Hammer, M.; Heller, T.; Jentsch, S.; Dawczynski, J.; Schweitzer, D.; Peters, S.; Schmidtke, K.U.; Müller, U.A. Retinal vessel oxygen saturation under flicker light stimulation in patients with nonproliferative diabetic retinopathy. Investig. Ophthalmol. Vis. Sci. 2012, 53, 4063-4068. [CrossRef]

83. Vandewalle, E.; Pinto, L.A.; Olafsdottir, O.B.; De Clerck, E.; Stalmans, P.; Van Calster, J.; Zeyen, T.; Stefánsson, E.; Stalmans, I. Oximetry in Glaucoma: Correlation of Metabolic Change With Structural and Functional Damage. Acta Ophthalmol. 2014, 92, 105-110. [CrossRef]

84. Battu, R.; Mohan, A.; Khanna, A.; Kumar, A.; Shetty, R. Retinal Oxygen Saturation in Retinitis Pigmentosa and Macular Dystrophies in Asian-Indian Eyes. Investig. Ophthalmol. Vis. Sci. 2015, 56, 2798-2802. [CrossRef] 
85. Eliasdottir, T.S.; Bragason, D.; Hardarson, S.H.; Kristjansdottir, G.; Stefánsson, E. Venous Oxygen Saturation Is Reduced and Variable in Central Retinal Vein Occlusion. Graefes Arch. Clin. Exp. Ophthalmol. 2015, 253, 1653-1661. [CrossRef]

86. Rilvén, S.; Torp, T.L.; Grauslund, J. Retinal oximetry in patients with ischaemic retinal diseases. Acta Ophthalmol. 2017, 95, 119-127. [CrossRef]

87. London, A.; Benhar, I.; Schwartz, M. The retina as a window to the brain-from eye research to CNS disorders. Nat. Rev. Neurol. 2013, 9, 44-53. [CrossRef]

88. DeBuc, D.C.; Somfai, G.M.; Koller, A. Retinal microvascular network alterations: Potential biomarkers of cerebrovascular and neural diseases. Am. J. Physiol. Heart Circ. Physiol. 2017, 312, H201-H212. [CrossRef] [PubMed]

89. Arthur, E.; Somfai, G.M.; Kostic, M.; Oropesa, S.; Santiesteban, C.M.; DeBuc, D.C. Distinguishing cognitive impairment by using singularity spectrum and lacunarity analysis of the retinal vascular network. Neurophotonics 2019, 6, 041109. [CrossRef] [PubMed]

90. Kur, J.; Newman, E.A.; Chan-Ling, T. Cellular and physiological mechanisms underlying blood flow regulation in the retina and choroid in health and disease. Prog. Retin Eye Res. 2012, 31, 377-406. [CrossRef] [PubMed]

91. Einarsdottir, A.B.; Olafsdottir, O.B.; Hjaltason, H.; Hardarson, S.H. Retinal oximetry is affected in multiple sclerosis. Acta Ophthalmol. 2018, 96, 528-530. [CrossRef] [PubMed]

92. Olafsdottir, O.B.; Saevarsdottir, H.S.; Hardarson, S.H.; Hannesdottir, K.H.; Traustadottir, V.D.; Karlsson, R.A.; Einarsdottir, A.B.; Jonsdottir, K.D.; Stefansson, E.; Snaedal, J. Retinal oxygen metabolism in patients with mild cognitive impairment. Alzheimers Dement. 2018, 10, 340-345. [CrossRef]

93. Jöbsis, F.F. Noninvasive, infrared monitoring of cerebral and myocardial oxygen sufficiency and circulatory parameters. Science 1977, 198, 1264-1267. [CrossRef]

94. Jöbsis-vanderVliet, F.F.; Jöbsis, P.D. Biochemical and physiological basis of medical near-infrared spectroscopy. J. Biomed. Opt. 1999, 4, 397-402. [CrossRef]

95. Matcher, S.J.; Cope, M.; Delpy, D.T. Use of the water absorption spectrum to quantify tissue chromophore concentration changes in near-infrared spectroscopy. Phys. Med. Biol. 1994, 38, 177-196. [CrossRef]

96. Matcher, S.J. Signal quantification and localization in tissue near-infrared spectroscopy. In Handbook of Optical Biomedical Diagnostics; Tuchin, V.V., Ed.; SPIE Press: Bellingham, WA, USA, 2002; Chapter 9.

97. Delpy, D.T.; Cope, M. Quantification in tissue near-infrared spectroscopy. Phil. Trans. R. Soc. Lond. B 1997, 352, 649-659. [CrossRef]

98. Chance, B. Spectrophotometry of intracellular respiratory pigments. Science 1954, 120, 767-775. [CrossRef] [PubMed]

99. Cope, M.; Delpy, D.T. System for long-term measurement of cerebral blood and tissue oxygenation on newborn infants by near infra-red transillumination. Med. Biol. Eng. Comput. 1988, 26, 289-294. [CrossRef]

100. Bickler, P.E.; Feiner, J.R.; Rollins, M.D. Factors Affecting the Performance of 5 Cerebral Oximeters During Hypoxia in Healthy Volunteers. Anesth. Analg. 2013, 117, 813-823. [CrossRef] [PubMed]

101. Phan, P.; Highton, D.; Lai, J.; Smith, M.; Elwell, C.; Tachtsidis, I. Multi-channel multi-distance broadband near-infrared spectroscopy system to measure the spatial response of cellular oxygen metabolism and tissue oxygenation. Biomed. Opt. Express 2016, 7, 4424-4440. [CrossRef] [PubMed]

102. De Blasi, R.A.; Ferrari, M.; Natali, A.; Conti, G.; Mega, A.; Gasparetto, A. Noninvasive measurement of forearm blood flow and oxygen consumption by near-infrared spectroscopy. J. Appl. Physiol. 1994, 76, 1388-1393. [CrossRef]

103. Feldmann, A.; Schmitz, R.; Erlacher, D. Near-infrared spectroscopy-derived muscle oxygen saturation on a $0 \%$ to $100 \%$ scale: Reliability and validity of the Moxy Monitor. J. Biomed. Opt. 2019, 24, 115001. [CrossRef]

104. Patterson, M.S.; Chance, B.; Wilson, B.C. Time resolved reflectance and transmittance for the non-invasive measurement of tissue optical properties. Appl. Opt. 1989, 28, 2331-2336. [CrossRef]

105. Fantini, S.; Franceschini, M.A.; Gratton, E. Semi-infinite-geometry boundary problem for light migration in highly scattering media-A frequency-domain study in the diffusion-approximation. J. Opt. Soc. Am. B Opt. Phys. 1994, 11, 2128-2138. [CrossRef]

106. Wilson, B.C.; Sevick, E.M.; Patterson, M.S.; Chance, B. Time-dependent optical spectroscopy and imaging for biomedical applications. Proc. IEEE 1992, 80, 918-930. [CrossRef] 
107. Suzuki, S.; Takasaki, S.; Ozaki, T.; Kobayashi, Y. Tissue oxygenation monitor using NIR spatially resolved spectroscopy. Proc. SPIE 1999, 3597, 582-592.

108. Liu, H.; Boas, D.A.; Zhang, Y.; Yodh, A.G.; Chance, B. Determination of optical properties and blood oxygenation in tissue using continuous NIR light. Phys. Med. Biol. 1995, 40, 1983-1993. [CrossRef] [PubMed]

109. Al-Rawi, P.G.; Smielewski, P.; Hobbiger, H.; Ghosh, S.; Kirkpatrick, P.J. Assessment of spatially resolved spectroscopy during cardiopulmonary bypass. J. Biomed. Opt. 1999, 4, 208-216. [CrossRef] [PubMed]

110. Kovacsova, Z.; Bale, G.; Mitra, S.; de Roever, I.; Meek, J.; Robertson, N.; Tachtsidis, I. Investigation of Confounding Factors in Measuring Tissue Saturation with NIRS Spatially Resolved Spectroscopy. In Oxygen Transport to Tissue XL; Advances in Experimental Medicine and Biology Series; Thews, O., LaManna, J., Harrison, D., Eds.; Springer: Cham, Switzerland, 2018; Volume 1072.

111. Sorensen, L.C.; Greisen, G. Precision of measurement of cerebral tissue oxygenation index using near-infrared spectroscopy in preterm neonates. J. Biomed. Opt. 2006, 11, 054005. [CrossRef] [PubMed]

112. Wolf, M.; Ferrari, M.; Quaresima, V. Progress of near-infrared spectroscopy and topography for brain and muscle clinical applications. J. Biomed. Opt. 2007, 12, 062104. [PubMed]

113. Star, W.M.; Marijnissen, J.P.A.; Gemert, M.J.C. Light dosimetry in optical phantoms and in tissues: I. Multiple flux and transport theory. Phys. Med. Biol. 1988, 33, 437-454. [CrossRef]

114. MacLeod, D.B.; Ikeda, K.; Vacchiano, C.; Lobbestael, A.; Wahr, J.A.; Shaw, A.D. Development and validation of a cerebral oximeter capable of absolute accuracy. J. Cardiothorac. Vasc. Anesth. 2012, 26, 1007-1014. [CrossRef]

115. Redford, D.; Paidy, S.; Kashif, F. Absolute and trend accuracy of a new regional oximeter in healthy volunteers during controlled hypoxia. Anesth. Analg. 2014, 119, 1315-1319. [CrossRef]

116. Ikeda, K.; MacLeod, D.B.; Grocott, H.P.; Moretti, E.W.; Ames, W.; Vacchiano, C. The accuracy of a near-infrared spectroscopy cerebral oximetry device and its potential value for estimating jugular venous oxygen saturation. Anesth. Analg. 2014, 119, 1381-1392. [CrossRef]

117. Weigl, W.; Milej, D.; Janusek, D.; Wojtkiewicz, S.; Sawosz, P.; Kacprzak, M.; Gerega, A.; Maniewski, R.; Liebert, A. Application of optical methods in the monitoring of traumatic brain injury: A review. J. Cereb. Blood Flow Metab. 2016, 36, 1825-1843. [CrossRef]

118. Mathieu, F.; Khellaf, A.; Ku, J.C.; Donnelly, J.; Thelin, E.P.; Zeiler, F.A. Continuous Near-Infrared Spectroscopy Monitoring in Adult Traumatic Brain Injury: A Systematic Review. J. Neurosurg. Anesthesiol. 2019, 10, 1097. [CrossRef]

119. Davie, S.N.; Grocott, H.P. Impact of extracranial contamination on regional cerebral oxygen saturation: A comparison of three cerebral oximetry technologies. Anesthesiology 2012, 116, 834-840. [CrossRef] [PubMed]

120. Strangman, G.; Franceschini, M.A.; Boas, D.A. Factors affecting the accuracy of near-infrared spectroscopy concentration calculations for focal changes in oxygenation parameters. Neuroimage 2003, 18, 865-879. [CrossRef]

121. Bozkurt, A.; Rosen, A.; Rosen, H.; Onaral, B. A portable near infrared Spectroscopy system for bedside monitoring of newborn brain. Biomed. Eng. Online 2005, 29, 29. [CrossRef] [PubMed]

122. Delpy, D.T.; Cope, M.; van der Zee, P.; Arridge, S.; Wray, S.; Wyatt, J. Estimation of optical pathlength through tissue from direct time of flight measurement. Phys. Med. Biol. 1988, 33, 1433-1442. [CrossRef]

123. Villringer, A.; Dirnagl, U. Coupling of brain activity and cerebral blood flow: Basis of functional neuroimaging. Cerebrovasc. Brain Metab. Rev. 1995, 7, 240-276. [PubMed]

124. Mackert, B.M.; Wübbeler, G.; Leistner, S.; Uludag, K.; Obrig, H.; Villringer, A.; Trahms, L.; Curio, G. Neurovascular coupling analyzed non-invasively in the human brain. Neuroreport 2004, 15, 63-66. [CrossRef]

125. Scholkmann, F.; Kleiser, S.; Metz, A.J.; Zimmermann, R.; Mata Pavia, J.; Wolf, U.; Wolf, M. A review on continuous wave functional near-infrared spectroscopy and imaging instrumentation and methodology. Neuroimage 2014, 85, 6-27. [CrossRef]

126. Lee, C.W.; Cooper, R.J.; Austin, T. Diffuse optical tomography to investigate the newborn brain. Pediatr. Res. 2017, 82, 376-386. [CrossRef]

127. Doulgerakis, M.; Eggebrecht, A.T.; Dehghani, H. High-density functional diffuse optical tomography based on frequency-domain measurements improves image quality and spatial resolution. Neurophotonics 2019, 6, 035007. [CrossRef]

128. Liao, S.M.; Ferradal, S.L.; White, B.R.; Gregg, N.; Inder, T.E.; Culver, J.P. High-density diffuse optical tomography of term infant visual cortex in the nursery. J. Biomed. Opt. 2012, 17, 081414. [CrossRef] 
129. Ferradal, S.L.; Liao, S.M.; Eggebrecht, A.T.; Shimony, J.S.; Inder, T.E.; Culver, J.P.; Smyser, C.D. Functional Imaging of the Developing Brain at the Bedside Using Diffuse Optical Tomography. Cereb. Cortex 2016, 26, 1558-1568. [CrossRef] [PubMed]

130. Karen, T.; Kleiser, S.; Ostojic, D.; Isler, H.; Guglielmini, S.; Bassler, D.; Wolf, M.; Scholkmann, F. Cerebral hemodynamic responses in preterm-born neonates to visual stimulation: Classification according to subgroups and analysis of frontotemporal-occipital functional connectivity. Neurophotonics 2019, 6, 045005. [CrossRef] [PubMed]

131. Wood, M.D.; Khan, J.; Lee, K.F.H.; Maslove, D.M.; Muscedere, J.; Hunt, M.; Scott, S.H.; Day, A.; Jacobson, J.; Ball, I.; et al. Assessing the relationship between near-infrared spectroscopy-derived regional cerebral oxygenation and neurological dysfunction in critically ill adults: A prospective observational multicentre protocol, on behalf of the Canadian Critical Care Trials Group. BMJ Open 2019, 25, e029189.

132. Wood, M.D.; Jacobson, J.A.; Maslove, D.M.; Muscedere, J.G.; Boyd, J.G. Cerebral Oxygenation and Neurological Outcomes Following Critical Illness (CONFOCAL) Research Group. The physiological determinants of near-infrared spectroscopy-derived regional cerebral oxygenation in critically ill adults. Intensive Care Med. Exp. 2019, 7, 23. [CrossRef] [PubMed]

133. Bendahan, N.; Neal, O.; Ross-White, A.; Muscedere, J.; Boyd, J.G. Relationship Between Near-Infrared Spectroscopy-Derived Cerebral Oxygenation and Delirium in Critically Ill Patients: A Systematic Review. J. Intensive Care Med. 2019, 34, 514-520. [CrossRef] [PubMed]

134. He, L.; Baker, W.B.; Milej, D.; Kavuri, V.C.; Mesquita, R.C.; Busch, D.R.; Abramson, K.; Jiang, J.Y.; Diop, M.; St. Lawrence, K.; et al. Noninvasive continuous optical monitoring of absolute cerebral blood flow in critically ill adults. Neurophotonics 2018, 5, 045006.

135. La Cour, A.; Greisen, G.; Hyttel-Sorensen, S. In vivo validation of cerebral near-infrared spectroscopy: A review. Neurophotonics 2018, 5, 040901. [CrossRef]

136. Rosenthal, G.; Furmanov, A.; Itshayek, E.; Shoshan, Y.; Singh, V. Assessment of a noninvasive cerebral oxygenation monitor in patients with severe traumatic brain injury: Clinical article. J. Neurosurg. 2014, 120, 901-907. [CrossRef]

137. Ito, H.; Kanno, I.; Iida, H.; Hatazawa, J.; Shimosegawa, E.; Tamura, H.; Okudera, T. Arterial fraction of cerebral blood volume in humans measured by positron emission tomography. Ann. Nucl Med. 2001, 15, 111-116. [CrossRef]

138. Kreeger, R.N.; Ramamoorthy, C.; Nicolson, S.C.; Ames, W.A.; Hirsch, R.; Peng, L.F.; Glatz, A.C.; Hill, K.D.; Hoffman, J.; Tomasson, J.; et al. Evaluation of pediatric near-infrared cerebral oximeter for cardiac disease. Ann. Thorac. Surg. 2012, 94, 1527-1533. [CrossRef]

139. Kussman, B.D.; Laussen, P.C.; Benni, P.B.; McGowan, F.X., Jr.; McElhinney, D.B. Cerebral Oxygen Saturation in Children with Congenital Heart Disease and Chronic Hypoxemia. Anesth. Analg. 2017, 125, 234-240. [CrossRef] [PubMed]

140. Benni, P.B.; MacLeod, D.; Ikeda, K.; Lin, H.M. A validation method for near-infrared spectroscopy based tissue oximeters for cerebral and somatic tissue oxygen saturation measurements. J. Clin. Monit. Comput. 2018, 32, 269-284. [CrossRef] [PubMed]

141. Leal-Noval, S.R.; Cayuela, A.; Arellano-Orden, V.; Marín-Caballos, A.; Padilla, V.; Ferrándiz-Millón, C.; Corcia, Y.; García-Alfaro, C.; Amaya-Villar, R.; Murillo-Cabezas, F. Invasive and noninvasive assessment of cerebral oxygenation in patients with severe traumatic brain injury. Intensive Care Med. 2010, 36, 1309-1317. [CrossRef] [PubMed]

142. Esnault, P.; Boret, H.; Montcriol, A.; Carre, E.; Prunet, B.; Bordes, J.; Simon, P.; Joubert, C.; Dagain, A.; Kaiser, E.; et al. Assessment of cerebral oxygenation in neurocritical care patients: Comparison of a new four wavelengths forehead regional saturation in oxygen sensor (EQUANOX) with brain tissue oxygenation. A prospective observational study. Minerva Anestesiol. 2015, 81, 876-884. [PubMed]

143. Arri, S.J.; Muehlemann, T.; Biallas, M.; Bucher, H.U.; Wolf, M. Precision of cerebral oxygenation and hemoglobin concentration measurements in neonates measured by near-infrared spectroscopy. J. Biomed. Opt. 2011, 16, 047005. [CrossRef]

144. Kleiser, S.; Ostojic, D.; Nasseri, N.; Isler, H.; Bucher, H.U.; Bassler, D.; Wolf, M.; Scholkmann, F.; Karen, T. In vivo precision assessment of a near-infrared spectroscopy-based tissue oximeter (OxyPrem v1.3) in neonates considering systemic hemodynamic fluctuations. J. Biomed. Opt. 2018, 23, 067003. [CrossRef] 
145. Murkin, J.M.; Adams, S.J.; Novick, R.J.; Quantz, M.; Bainbridge, D.; Iglesias, I.; Cleland, A.; Schaefer, B.; Irwin, B.; Fox, S. Monitoring brain oxygen saturation during coronary bypass surgery: A randomized, prospective study. Anesth. Analg. 2007, 104, 51-58. [CrossRef]

146. Slater, J.P.; Guarino, T.; Stack, J.; Vinod, K.; Bustami, R.T.; Brown, J.M., 3rd; Rodriguez, A.L.; Magovern, C.J.; Zaubler, T.; Freundlich, K.; et al. Cerebral oxygen desaturation predicts cognitive decline and longer hospital stay after cardiac surgery. Ann. Thorac. Surg. 2009, 87, 36-44. [CrossRef]

147. Vohra, H.A.; Modi, A.; Ohri, S.K. Does use of intra-operative cerebral regional oxygen saturation monitoring during cardiac surgery lead to improved clinical outcomes? Interact. Cardiovasc. Thorac. Surg. 2009, 9, 318-322. [CrossRef]

148. Zheng, F.; Sheinberg, R.; Yee, M.S.; Ono, M.; Zheng, Y.; Hogue, C.W. Cerebral near-infrared spectroscopy monitoring and neurologic outcomes in adult cardiac surgery patients: A systematic review. Anesth. Analg. 2013, 116, 663-676. [CrossRef]

149. Holmgaard, F.; Vedel, A.G.; Rasmussen, L.S.; Paulson, O.B.; Nilsson, J.C.; Ravn, H.B. The association between postoperative cognitive dysfunction and cerebral oximetry during cardiac surgery: A secondary analysis of a randomised trial. Br. J. Anaesth. 2019, 123, 196-205. [CrossRef]

150. Uysal, S.; Lin, H.M.; Trinh, M.; Park, C.H.; Reich, D.L. Optimizing cerebral oxygenation in cardiac surgery: A randomized controlled trial examining neurocognitive and perioperative outcomes. J. Thorac. Cardiovasc. Surg. 2020, 159, 943-953.e3. [CrossRef]

151. Yu, Y.; Zhang, K.; Zhang, L.; Zong, H.; Meng, L.; Han, R. Cerebral near-infrared spectroscopy (NIRS) for perioperative monitoring of brain oxygenation in children and adults. Cochrane Database Syst. Rev. 2018, 1, CD010947. [CrossRef]

152. Hyttel-Sorensen, S.; Pellicer, A.; Alderliesten, T.; Austin, T.; van Bel, F.; Benders, M.; Claris, O.; Dempsey, E.; Franz, A.R.; Fumagalli, M.; et al. Cerebral near infrared spectroscopy oximetry in extremely preterm infants: Phase II randomised clinical trial. BMJ 2015, 350, g7635. [CrossRef]

153. Plomgaard, A.M.; van Oeveren, W.; Petersen, T.H.; Alderliesten, T.; Austin, T.; van Bel, F.; Benders, M.; Claris, O.; Dempsey, E.; Franz, A.; et al. The SafeBoosC II randomized trial: Treatment guided by near-infrared spectroscopy reduces cerebral hypoxia without changing early biomarkers of brain injury. Pediatr. Res. 2016, 79, 528-535. [CrossRef] [PubMed]

154. Plomgaard, A.M.; Alderliesten, T.; van Bel, F.; Benders, M.; Claris, O.; Cordeiro, M.; Dempsey, E.; Fumagalli, M.; Gluud, C.; Hyttel-Sorensen, S.; et al. No neurodevelopmental benefit of cerebral oximetry in the first randomised trial (SafeBoosC II) in preterm infants during the first days of life. Acta Paediatr. 2019, 108, 275-281. [CrossRef] [PubMed]

155. Fischer, G.W.; Lin, H.M.; Krol, M.; Galati, M.F.; Di Luozzo, G.; Griepp, R.B.; Reich, D.L. Noninvasive cerebral oxygenation may predict outcome in patients undergoing aortic arch surgery. J. Thorac. Cardiovasc. Surg. 2011, 141, 815-821. [CrossRef] [PubMed]

156. Wen, S.; Peng, A.; Boyle, S.; Cai, S.; Pope, L.; Tran, M.T.; Short, T.G.; Aneman, A.; Jaeger, M.; Chuan, A. A pilot study using preoperative cerebral tissue oxygen saturation to stratify cardiovascular risk in major non-cardiac surgery. Anaesth. Intensive Care 2017, 45, 202-209. [CrossRef] [PubMed]

157. Pfister, D.; Siegemund, M.; Dell-Kuster, S.; Smielewski, P.; Rüegg, S.; Strebel, S.P.; Marsch, S.C.U.; Pargger, H.; Pargger, L.A. Cerebral perfusion in sepsis-associated delirium. Crit. Care 2008, 12, R63. [CrossRef] [PubMed]

158. Vaskó, A.; Siró, P.; László, I.; Szatmári, S.; Molnár, L.; Fülesdi, B.; Molnár, C. Assessment of cerebral tissue oxygen saturation in septic patients during acetazolamide provocation-A near infrared spectroscopy study. Acta Physiol. Hung. 2014, 101, 32-39. [CrossRef]

159. Wood, M.; Song, A.; Maslove, D.; Ferri, C.; Howes, D.; Muscedere, J.; Boyd, J.G. Brain Tissue Oxygenation in Patients with Septic Shock: A Feasibility Study. Can. J. Neurol. Sci. 2016, 43, 65-73. [CrossRef]

160. Wood, M.D.; Maslove, D.M.; Muscedere, J.G.; Day, A.G.; Gordon Boyd, J. Low brain tissue oxygenation contributes to the development of delirium in critically ill patients: A prospective observational study. J. Crit. Care. 2017, 41, 289-295. [CrossRef] [PubMed]

161. Davies, D.J.; Su, Z.; Clancy, M.T.; Lucas, S.J.E.; Dehghani, H.; Logan, A.; Belli, A. Near-Infrared Spectroscopy in the Monitoring of Adult Traumatic Brain Injury: A Review. J. Neurotrauma 2015, 32, 933-941. [CrossRef] [PubMed]

162. Panerai, R.B. Assessment of cerebral pressure autoregulation in humans-a review of measurement methods. Physiol. Meas. 1998, 19, 305-338. [CrossRef] [PubMed] 
163. Willie, C.K.; Tzeng, Y.-C.; Fisher, J.A.; Ainslie, P.N. Integrative regulation of human brain blood flow. J. Physiol. 2014, 592, 841-859. [CrossRef] [PubMed]

164. Ainslie, P.N.; Brassard, P. Why is the neural control of cerebral autoregulation so controversial? F1000Prime Rep. 2014, 6, 14. [CrossRef]

165. Liu, X.; Czosnyka, M.; Donnelly, J.; Budohoski, K.P.; Varsos, G.V.; Nasr, N.; Brady, K.M.; Reinhard, M.; Hutchinson, P.J.; Smielewski, P. Comparison of frequency and time domain methods of assessment of cerebral autoregulation in traumatic brain injury. J. Cereb. Blood Flow Metab. 2015, 35, 248-256. [CrossRef]

166. Steiner, L.A.; Pfister, D.; Strebel, S.P.; Radolovich, D.; Smielewski, P.; Czosnyka, M. Near-infrared spectroscopy can monitor dynamic cerebral autoregulation in adults. Neurocrit. Care 2009, 10, 122-128. [CrossRef]

167. Brady, K.; Joshi, B.; Zweifel, C.; Smielewski, P.; Czosnyka, M.; Easley, R.B.; Hogue, C.W., Jr. Real-time continuous monitoring of cerebral blood flow autoregulation using near-infrared spectroscopy in patients undergoing cardiopulmonary bypass. Stroke 2010, 41, 1951-1956. [CrossRef]

168. Sen, A.N.; Gopinath, S.P.; Robertson, C.S. Clinical application of near-infrared spectroscopy in patients with traumatic brain injury: A review of the progress of the field. Neurophotonics 2016, 3, 031409. [CrossRef]

169. Highton, D.; Ghosh, A.; Tachtsidis, I.; Panovska-Griffiths, J.; Elwell, C.E.; Smith, M. Monitoring cerebral autoregulation after brain injury: Multimodal assessment of cerebral slow-wave oscillations using near-infrared spectroscopy. Anesth. Analg. 2015, 121, 198-205. [CrossRef] [PubMed]

170. Liu, X.; Czosnyka, M.; Donnelly, J.; Cardim, D.; Cabeleira, M.; Lalou, D.A.; Hu, X.; Hutchinson, P.J.; Smielewski, P. Assessment of cerebral autoregulation indices-A modelling perspective. Sci. Rep. 2020, 10, 9600. [CrossRef] [PubMed]

171. Brady, K.M.; Mytar, J.O.; Lee, J.K.; Cameron, D.E.; Vricella, L.A.; Thompson, W.R.; Hogue, C.W.; Easley, R.B. Monitoring cerebral blood flow pressure autoregulation in pediatric patients during cardiac surgery. Stroke 2010, 41, 1957-1962. [CrossRef] [PubMed]

172. Tichauer, K.M.; Elliott, J.T.; Hadway, J.A.; Lee, D.S.; Lee, T.Y.; St Lawrence, K. Using near-infrared spectroscopy to measure cerebral metabolic rate of oxygen under multiple levels of arterial oxygenation in piglets. J. Appl. Physiol. 2010, 109, 878-885. [CrossRef] [PubMed]

173. Kim, H.Y.; Seo, K.; Jeon, H.J.; Lee, U.; Lee, H. Application of Functional Near-Infrared Spectroscopy to the Study of Brain Function in Humans and Animal Models. Mol. Cells 2017, 40, 523-532. [CrossRef] [PubMed]

174. Nakamura, S.; Walker, D.W.; Wong, F.Y. Cerebral haemodynamic response to somatosensory stimulation in near-term fetal sheep. J. Physiol. 2017, 595, 1289-1303. [CrossRef]

175. El-Sabbagh, A.M.; Gray, B.W.; Shaffer, A.W.; Bryner, B.S.; Church, J.T.; McLeod, J.S.; Zakem, S.; Perkins, E.M.; Shellhaas, R.A.; Barks, J.D.E.; et al. Cerebral Oxygenation of Premature Lambs Supported by an Artificial Placenta. ASAIO J. 2018, 64, 552-556. [CrossRef]

176. Kurita, T.; Kawashima, S.; Morita, K.; Nakajima, Y. Spinal cord autoregulation using near-infrared spectroscopy under normal, hypovolemic, and post-fluid resuscitation conditions in a swine model: A comparison with cerebral autoregulation. J. Intensive Care 2020, 8, 27. [CrossRef]

(C) 2020 by the authors. Licensee MDPI, Basel, Switzerland. This article is an open access article distributed under the terms and conditions of the Creative Commons Attribution (CC BY) license (http://creativecommons.org/licenses/by/4.0/). 